\title{
Repurposing metformin for cancer treatment: current clinical studies
}

\author{
Young Kwang Chae ${ }^{1,2,3}$, Ayush Arya ${ }^{3}$, Mary-Kate Malecek ${ }^{3}$, Daniel Sanghoon Shin ${ }^{4}$, \\ Benedito Carneiro ${ }^{1,2,3}$, Sunandana Chandra ${ }^{1,2,3}$, Jason Kaplan ${ }^{1,2,3}$, Aparna Kalyan ${ }^{1,2,3}$, \\ Jessica K. Altman ${ }^{1,2,3}$, Leonidas Platanias ${ }^{1,2,3,5}$ and Francis Giles ${ }^{1,2,3}$ \\ ${ }^{1}$ Northwestern Medicine Developmental Therapeutics Institute, Chicago, IL, USA \\ ${ }^{2}$ Robert H. Lurie Comprehensive Cancer Center of Northwestern University, Chicago, IL, USA \\ ${ }^{3}$ Northwestern University Feinberg School of Medicine, Chicago, IL, USA \\ ${ }^{4}$ David Geffen School of Medicine, University of California Los Angeles, Los Angeles, CA, USA \\ ${ }^{5}$ Division of Hematology-Oncology, Department of Medicine, Jesse Brown VA Medical Center, Chicago, IL, USA \\ Correspondence to: Young Kwang Chae, email: young.chae@northwestern.edu \\ Keywords: metformin, clinical trials, cancer \\ Received: September 20, $2015 \quad$ Accepted: March 06, $2016 \quad$ Published: March 19, 2016
}

\section{ABSTRACT}

In recent years, several studies have presented evidence suggesting a potential role for metformin in anti-cancer therapy. Preclinical studies have demonstrated several anticancer molecular mechanisms of metformin including mTOR inhibition, cytotoxic effects, and immunomodulation. Epidemiologic data have demonstrated decreased cancer incidence and mortality in patients taking metformin. Several clinical trials, focused on evaluation of metformin as an anti-cancer agent are presently underway. Data published from a small number of completed trials has put forth intriguing results. Clinical trials in pre-surgical endometrial cancer patients exhibited a significant decrease in Ki67 with metformin monotherapy. Another interesting observation was made in patients with breast cancer, wherein a trend towards improvement in cancer proliferation markers was noted in patients without insulin resistance. Data on survival outcomes with the use of metformin as an anti-cancer agent is awaited. This manuscript will critically review the role of metformin as a potential cancer treatment.

\section{INTRODUCTION}

Metformin is one of the most widely prescribed oral anti-diabetic medications. It is the first line therapy for type 2 diabetes mellitus [1]. It has an anti-hyperglycemic effect which is mediated by inhibiting gluconeogenesis, decreasing glucose absorption from the small intestine, increasing glucose uptake in cells, and decreasing plasma free fatty acid concentration [2]. Metformin also increases insulin induced translocation of glucose transporters to the cellular plasma membrane, thus reducing insulin resistance [3]. Use of metformin has been found to be generally safe, with mild gastrointestinal symptoms being the most common adverse effects [4].

There is substantial preclinical evidence suggesting that metformin has anti-cancer properties. In-vitro and invivo analysis of metformin has exhibited anti-proliferative activity by inhibiting intracellular pathways. It has also been observed that metformin activates the $\mathrm{T}$ cell mediated immune response against cancer cells.

Numerous retrospective studies have reported that metformin is associated with a reduced risk of developing cancer. Meta-analysis of data obtained from cohort and observational studies has revealed that metformin use was associated with a decrease in both cancer related and allcause mortality.

Here we summarize the available evidence from clinical trials of metformin as part of cancer therapy. We review the landscape of current investigation and suggest directions for future investigation.

\section{PRECLINICAL DATA}

Metformin has been extensively studied in preclinical models, which has revealed numerous molecular pathways that it modulates, either directly 
Table 1: Proof of concept for anti-tumor activity of metformin

\begin{tabular}{|c|c|c|c|c|c|c|c|c|}
\hline Cancer type & Phase & $\begin{array}{l}\text { Primary outcome/ } \\
\text { Conclusion }\end{array}$ & Dosing regimen & Combination & $\begin{array}{l}\text { Enrollment } \\
\text { No. }\end{array}$ & Status & Results & $\begin{array}{lr}\text { Clinical trial } \\
\text { identifier/Reference }\end{array}$ \\
\hline Bladder & Phase II & $\begin{array}{l}\text { Changes in Ki67 } \\
\text { when comparing } \\
\text { TURBT and } \\
\text { cystectomy tissue. }\end{array}$ & $\begin{array}{l}\text { Metformin } 850 \mathrm{mg} \text { and } 20 \\
\mathrm{mg} \text { of Simvastatin daily } \\
\text { from the time of enrollment } \\
\text { in study untill the day before } \\
\text { surgery (an approximate } \\
\text { duration of } 12 \text { weeks) }\end{array}$ & $\begin{array}{l}\text { metformin, } \\
\text { simvastatin }\end{array}$ & 44 & $\begin{array}{l}\text { Not yet } \\
\text { recruiting }\end{array}$ & NA & NCT02360618 \\
\hline Breast & Phase 0 & $\begin{array}{lr}\text { Tumor } & \text { growth } \\
\text { assessed } & \text { by } \\
\text { changes in } & \ln \mathrm{Ki67}\end{array}$ & $\begin{array}{l}\text { Metformin }+ \text { atorvastatin } \\
\text { PO }\end{array}$ & $\begin{array}{l}\text { metformin, } \\
\text { atorvastatin }\end{array}$ & 40 & Recruiting & NA & NCT01980823 \\
\hline Breast & Phase II & $\begin{array}{l}\text { Effects } \\
\text { of metformin on } \\
\text { AMPK/mTOR } \\
\text { pathway }\end{array}$ & $\begin{array}{l}\text { Metformin } 1500 \mathrm{mg} / \mathrm{day}, \\
500 \mathrm{mg}(\mathrm{AM}) \text { and } 1000 \mathrm{mg} \\
(\mathrm{PM}) \text { for at least } 2 \text { weeks } \\
\text { prior to surgery }\end{array}$ & $\begin{array}{l}\text { metformin } \\
\text { monotherapy }\end{array}$ & 35 & Published & $\begin{array}{l}\text { - Non-significant difference in decrease of } \\
\text { ln (Ki67) for both invasive and DCIS breast } \\
\text { cancers }(p=0.98) \text { or invasive breast cancer } \\
\text { alone }(\mathrm{p}=0.43) \text {. } \\
\text { - No significant variation noted in changes of } \\
\text { ln (Ki67) when metformin arm compared to } \\
\text { control arm }(\mathrm{p}=.47) \text {. }\end{array}$ & $\begin{array}{l}\text { NCT00930579 } \\
{[41]}\end{array}$ \\
\hline Breast & Phase II & $\begin{array}{l}\text { Effects } \\
\text { of metformin in } \\
\text { phosphorylation of } \\
\text { S6K, 4E-BP-1 and } \\
\text { AMPK }\end{array}$ & $\begin{array}{l}\text { Extended release } \\
\text { metformin 1500mg QD for } \\
14-21 \text { days }\end{array}$ & $\begin{array}{l}\text { metformin } \\
\text { monotherapy }\end{array}$ & 41 & Completed & NA & NCT01266486 \\
\hline Breast & $\begin{array}{l}\text { Phase II } \\
\text { RCT }\end{array}$ & $\begin{array}{l}\text { Primary endpoint } \\
\text { is change in } \\
\text { Ki67. This study } \\
\text { estimates apoptosis } \\
\text { by TUNEL by } \\
\text { comparing core } \\
\text { and corresponding } \\
\text { surgical biopsies. }\end{array}$ & $\begin{array}{l}\text { Metformin } 850 \mathrm{mg} \text { QD for } \\
3 \text { days followed by } 850 \mathrm{mg} \\
\text { BID days } 4-28\end{array}$ & $\begin{array}{l}\text { metformin } \\
\text { monotherapy }\end{array}$ & 200 & Published & $\begin{array}{l}\text { TUNEL levels elevated at surgery as } \\
\text { compared to baseline biopsy }(\mathrm{P}<0.0001) \text {, } \\
\text { no major difference between metformin } \\
\text { arm and placebo arm; Ki67 labelling index } \\
\text { and TUNEL levels at baseline \& surgery in } \\
\text { direct correlation; TUNEL levels higher with } \\
\text { metformin than placebo in women without } \\
\text { insulin resistance (metformin: }+4 \% \text {, IQR: } \\
2-14 \text {, placebo: }+2 \% \text {, IQR: } 0-7 \text {, while the } \\
\text { inverse observed in those who had insulin } \\
\text { resistance (metformin: +2\%, IQR: } 0-6 \text {, } \\
\text { placebo }+5 \% \text {, IQR: } 0-15) \text {. }\end{array}$ & $\begin{array}{lr}\text { EudraCT } & 2008- \\
004912-10, & \text { Trial } \\
\text { number } & \text { S425/408 } \\
{[42]} & \end{array}$ \\
\hline Breast & $\begin{array}{l}\text { Phase II, } \\
\text { single arm }\end{array}$ & $\begin{array}{l}\text { Effect of metformin } \\
\text { on tumor growth } \\
\text { rate over } 2 \text { to } 3 \\
\text { weeks }\end{array}$ & $\begin{array}{l}\text { Metformin } 500 \mathrm{mg} \text { PO TID } \\
\text { for 2-3 weeks before surgery }\end{array}$ & $\begin{array}{l}\text { metformin } \\
\text { monotherapy }\end{array}$ & 39 & Completed & $\begin{array}{l}\text { HOMA levels significantly reduced; insulin, } \\
\text { leptin and CRP had non-significant reductions; } \\
\text { TUNEL staining increased from } 0.56 \text { to } 1.05 \text {, } \\
p=0.004 ; \text { Ki67 staining decreased from } 36.5 \\
\text { to } 33.5 \%, p=0.016 \text {. }\end{array}$ & NCT00897884 [37] \\
\hline Breast & $\begin{array}{l}\text { Phase II } \\
\text { RCT }\end{array}$ & Changes in $\mathrm{Ki}-67$ & $\begin{array}{l}\text { Metformin } 850 \text {-mg QDPO } \\
\text { days } 1-3 \text { for allowing time } \\
\text { to adjust to GI symptoms; } \\
\text { two } 850 \mathrm{mg} \text { tablets after } \\
\text { dinner on days } 4-28 \text {. }\end{array}$ & $\begin{array}{l}\text { metformin } \\
\text { monotherapy }\end{array}$ & 200 & Completed & $\begin{array}{l}\text { No statistically significant changes in Ki67 } \\
\text { with metformin, noting a mean proportional } \\
\text { increase of } 4.0 \% \text { ( } 95 \% \text { CI: }-5.6 \% \text { to } 14.4 \%) \\
\text { in } 4 \text { weeks; } \\
\text { Women with HOMA } \leq 2.8: \text { non-significant } \\
\text { increase of Ki67 by } 11.1 \% \text { ( } 95 \% \text { CI: }-0.6 \% \\
\text { to } 24.2 \%) \text {; women with HOMA }>2.8: \text { non- } \\
\text { significant mean proportional decrease in } \\
\text { Ki67 by } 10.5 \% \text { ( } 95 \% \text { CI: }-26.1 \% \text { to } 8.4 \%) \text {. }\end{array}$ & $\begin{array}{l}\text { ISRCTN16493703 } \\
{[40]}\end{array}$ \\
\hline Breast & NA, RCT & $\begin{array}{l}\text { To determine } \\
\text { the anti-cancer } \\
\text { mechanism of } \\
\text { metformin in } \\
\text { breast cancer }\end{array}$ & $\begin{array}{l}\text { Metformin 500mg QD for } 1 \\
\text { week followed by } 1000 \mathrm{mg} \\
\text { BID until the day of surgery }\end{array}$ & $\begin{array}{l}\text { metformin } \\
\text { monotherapy }\end{array}$ & 47 & Published & $\begin{array}{l}\text { Metformin therapy showed no effect on tumor } \\
\text { size. } \\
\text { With using Allred scoring (0-8)- } \\
\text { - Mean change in pAMPK score: } \\
\text { Metformin- } 5.18 \text { to } 6.45 \\
\text { Control arm- } 5.64 \text { to } 6.00 \\
\text { - Change in pAKT staining score: } \\
\text { Metformin- } 5.91 \text { to } 5.00 \\
\text { Control arm- } 4.91 \text { to } 5.18 \\
\text { - Mean change in Ki67 staining: } \\
\text { Metformin- decrease by } 3.4 \% \\
\text { Control arm- stable } \\
\text { - Caspase-3 staining: } \\
\text { Metformin- reduced by } 0.29 \% \\
\text { Control arm- no significant change }\end{array}$ & {$[39]$} \\
\hline $\begin{array}{l}\text { Breast, lung, } \\
\text { liver, kidney, } \\
\text { lymphoma }\end{array}$ & Phase 1 & $\begin{array}{l}\text { Effect of } \\
\text { metformin sirolimus } \\
\text { plus sirolimus } \\
\text { compared } \\
\text { to monotherapy on } \\
\text { monoS }\end{array}$ & $\begin{array}{l}\text { Sirolimus } 3 \mathrm{mg} \text { daily alone } \\
\text { for the first } 7 \text { days. From } \\
\text { day 8-21, metformin } \\
500 \mathrm{mg} \text { QD. If tolerated, } \\
\text { dose increased to } 1000 \mathrm{mg} \\
\text { QD on day } 15 \text {. Patients } \\
\text { developing grade } 2 \text { toxicity } \\
\text { due to metformin to be } \\
\text { maintained on } 500 \mathrm{mg} Q \mathrm{QD} \\
\text { for rest of study, while } \\
\text { those with > grade } 2 \text { toxicity } \\
\text { will be taken off study. Day } \\
22 \text { onwards, all will be on } \\
\text { combination of sirolimus + } \\
\text { metformin }\end{array}$ & $\begin{array}{l}\text { metformin, } \\
\text { sirolimus }\end{array}$ & 64 & Recruiting & NA & NCT02145559 \\
\hline Endometrial & Phase 0 & Changes in Ki-67 & Metformin $850 \mathrm{mg}$ PO QD & $\begin{array}{l}\text { metformin } \\
\text { monotherapy }\end{array}$ & 16 & Completed & $\begin{array}{l}65 \% \text { patients showed a fall in Ki- } 67 \text { staining } \\
\text { with metformin; those who showed response } \\
\text { to metformin had higher pre-treatment Ki67 } \\
\text { levels; pAMPK, pS6, pAKT, p-4E-BP-1 and } \\
\text { ER expression were reduced; PR unaffected; } \\
\text { tumor proliferation decreased by } 11.75 \% \text { with } \\
\text { metformin. }\end{array}$ & NCT01911247[43] \\
\hline Endometrial & Phase II & Changes in $\mathrm{pS} 6$ & $\begin{array}{l}\text { Metformin 500mg PO TID } \\
\text { from enrollment in study } \\
\text { till surgical staging. If side } \\
\text { effects persist, dose will be } \\
\text { reduced to } 500 \mathrm{mg} \text { PO BID. }\end{array}$ & $\begin{array}{l}\text { metformin } \\
\text { monotherapy }\end{array}$ & 80 & $\begin{array}{l}\text { Not yet } \\
\text { recruiting }\end{array}$ & NA & NCT02042495 \\
\hline
\end{tabular}




\begin{tabular}{|c|c|c|c|c|c|c|c|c|}
\hline Endometrial & $\begin{array}{l}\text { Phase II } \\
\text { RCT }\end{array}$ & $\begin{array}{l}\text { Changes in Ki67, } \\
\text { phosphorylated } \\
\text { histone H3, } \\
\text { estrogen receptor, } \\
\text { progesterone } \\
\text { receptor, and } \\
\text { telomerase. }\end{array}$ & NA & $\begin{array}{l}\text { metformin } \\
\text { monotherapy }\end{array}$ & 40 & Recruiting & NA & NCT01877564 \\
\hline Endometrial & NA & $\begin{array}{l}\text { Effect of metformin } \\
\text { on tumor } \\
\text { proliferation }\end{array}$ & $\begin{array}{l}\text { Metformin 500mg TID from } \\
\text { diagnostic biopsy to surgery } \\
\text { (average of } 36.6 \text { days) }\end{array}$ & $\begin{array}{l}\text { metformin } \\
\text { monotherapy }\end{array}$ & 11 & Published & $\begin{array}{l}\text { Metformin use decreased IGF-1, mean plasma } \\
\text { insulin, IGFBP-7, Ki67 (9.7\%, p= 0.02) and } \\
\text { pS6 (31\%, p= 0.03) staining; Ki67 and pS6 in } \\
\text { control group similar in baseline biopsy and } \\
\text { surgical specimens. }\end{array}$ & [44] \\
\hline Endometrial & NA & Increase in s6K & $\begin{array}{l}\text { Metformin } 850 \mathrm{mg} \text { QD for } \\
\text { at least } 7 \text { days and up to } 30 \\
\text { days before surgery }\end{array}$ & $\begin{array}{l}\text { metformin } \\
\text { monotherapy }\end{array}$ & 30 & $\begin{array}{l}\text { Active, but } \\
\text { not recruiting }\end{array}$ & NA & NCT01205672 \\
\hline Endometrial & NA & $\begin{array}{l}\text { Effect of anti- } \\
\text { diabetic dose of } \\
\text { metformin on } \\
\text { tumor proliferation }\end{array}$ & $\begin{array}{l}\text { Metformin } 1500-2250 \mathrm{mg} / \\
\text { day for } 4-6 \text { weeks before } \\
\text { surgery }\end{array}$ & $\begin{array}{l}\text { metformin } \\
\text { monotherapy }\end{array}$ & 31 & Published & $\begin{array}{l}\text { Ki-67 mean proportional decrease }=44.2 \% \text {; } \\
\text { topoisomerase II } \alpha \text { mean proportional } \\
\text { decrease }=36.4 \% \text {; PRP S6 and ERK1/2 levels } \\
\text { showed significant reduction while pAMPK } \\
\text { and p27 had significant elevation. }\end{array}$ & [45] \\
\hline $\begin{array}{l}\text { Head and Neck } \\
\text { squamous cell }\end{array}$ & Phase 0 & $\begin{array}{lr}\text { Changes } & \text { in } \\
\text { TOMM20 r and } \\
\text { MCT4 in tumor } \\
\text { tissue }\end{array}$ & NA & $\begin{array}{l}\text { metformin } \\
\text { monotherapy }\end{array}$ & 40 & Recruiting & NA & NCT02083692 \\
\hline Lung & Phase II & $\begin{array}{l}\text { Effect of metformin } \\
\text { on plasma IL-6 } \\
\text { levels }\end{array}$ & $\begin{array}{l}\text { Treatment with either } \\
\text { cisplatin } 75 \mathrm{mg} / \mathrm{m}^{2} \\
\text { pemetrexed } 500 \mathrm{mg} / \mathrm{m}^{2} \text { on } \\
\text { dayl for } 4 \text { cycles or targeted } \\
\text { therapy with gefitinib } \\
250 \mathrm{mg} / \text { day until disease } \\
\text { progression. If plasma IL-6 } 6 \\
>2.0 \mathrm{pg} / \mathrm{mL} \text { after } 2 \text { cycles } \\
\text { of chemotherapy/targeted } \\
\text { therapy, metformin } 500 \mathrm{mg} \\
\text { PO QD will be given on day } \\
1 \text { of cycle 3. If tolerated, } \\
\text { metformin will be titrated } \\
\text { to } 500 \mathrm{mg} \text { BID in next week } \\
\text { (Cycle } 3 \text { day8) and } 500 \mathrm{mg} \\
\text { TID in the } 3 \text { rd week (Cycle } \\
3 \text { day } 15) \text {; those receiving } \\
\text { chemo will be given } \\
\text { metformin for } 12 \text { weeks and } \\
\text { those on targeted therapy } \\
\text { will receive it till disease } \\
\text { progression. }\end{array}$ & $\begin{array}{l}\text { metformin, } \\
\text { cisplatin, } \\
\text { pemetrexed, } \\
\text { gefitinib }\end{array}$ & 48 & Recruiting & NA & NCT01997775 \\
\hline Prostate & $\begin{array}{l}\text { Phase II } \\
\text { RCT }\end{array}$ & $\begin{array}{l}\text { Changes in } \mathrm{Ki67} \\
\text { staining using } \\
\text { IHC }\end{array}$ & $\begin{array}{l}\text { Extended } \\
\text { metformin PO QD foase } \\
4-12 \text { weeks }\end{array}$ & $\begin{array}{l}\text { metformin } \\
\text { monotherapy }\end{array}$ & 21 & $\begin{array}{l}\text { Active } \\
\text { but not } \\
\text { recruiting }\end{array}$ & NA & NCT01433913 \\
\hline Prostate & NA & $\begin{array}{l}\text { Assess safety, } \\
\text { tolerability and } \\
\text { change in Ki67 and } \\
\text { AMPK pathway } \\
\text { associated markers } \\
\text { with the use of } \\
\text { neoadjuvant } \\
\text { metformin }\end{array}$ & Metformin 500mg TID & $\begin{array}{l}\text { Metformin } \\
\text { monotherapy }\end{array}$ & 24 & Published & $\begin{array}{l}\text { Metformin decreased Ki67 index by } 29.5 \% \\
\text { per patient and } 28.6 \% \text { per tumor; P-4EBP } 1 \\
\text { staining showed reduction and P-AMPK } \\
\text { recorded no change; } 3 \text { cases developed grade } \\
3 \text { toxicity. }\end{array}$ & {$[48]$} \\
\hline
\end{tabular}

Abbreviations: PFS, progression free survival; RCT, Randomized control trial; TUNEL, Terminal deoxynucleotidyl transferase dUTP nick end labeling; P-AMPK, phosphorylated AMPK; HOMA, Homeostasis model assessment; IGF-1, insulin like growth factor-1; IQR, Interquartile ratio; PO, taken by mouth; QD, once a day; BID, two times a day; TID, three times a day

or through other downstream targets, contributing to reduction in growth and proliferation of tumor cells. The inhibition of mTOR (mammalian target of rapamycin) in tumor cells is one of the potential key mechanisms that facilitates the anti-cancer activity of metformin. Use of metformin in MCF-7 breast cancer cells exhibited reduction in phosphorylation of S6 kinase, ribosomal protein S6 and eIF4E binding protein, along with inhibition of mTOR and reduced translation initiation due to AMPK activation [5]. Animal models of pancreatic cancer fed with metformin showed inhibition of insulin like growth factor-1 (IGF-1) and mTOR, along with an increase in phosphorylated AMPK and tuberous sclerosis complex (TSC1, TSC2) [6]. The AMPK mediated phosphorylation of TSC2 has been observed to increase the activity of TSC2, leading to inactivation of MTOR [7, 8]. AMPK has been described to directly inhibit mTORC1 through phosphorylation of mTOR binding raptor as well [9]. Comparing the effects of metformin with rapamycin, a direct mTOR inhibitor, metformin decreases the activation of AKT in addition to AMPK dependent mTOR inhibition. Thus, metformin renders a better anti-tumor response than rapamycin in breast cancer cells [10]. Metformin has been found to decrease HER2 expression in human breast cancer cells by directly inhibiting p70S6K1, which is a downstream effector of mTOR [11]. In a study using nude mice with acute myeloid leukemia (AML), the use of metformin was correlated with a decrease in proliferation of AML cells. This action was characterized by the activation of LKB1/AMPK/TSC pathway, which led to mTOR inhibition and consequently suppression of mRNA translation [12]. In tobacco carcinogen induced lung cancer mice, the inhibition of insulin like growth factor 1 receptor/insulin receptor (IGF-1R/IR) by metformin decreased the downstream signaling through Akt pathway. This reduced the activation of mTOR in lung tissue which corresponded to a $72 \%$ reduction in tumor burden [13].

Metformin can inhibit the activation of mTOR independent of AMPK pathway as well. Metformin has been shown to escalate the expression of REDD1 by 
a p53 mediated inhibition of mTOR in prostate cancer cells [14]. Another study described that metformin can prevent mTOR activation through Ras-related GTPase (RagGTPases), independent of AMPK, as well as TSC1/2 [15].

Tumors are known to exhibit the Warburg effect, where tumor cells generate ATP from glycolysis instead of oxidative phosphorylation secondary to low nutrient supply and hypoxia [16]. Metformin blunts the Warburg effect and consequently downregulates the growth of cancer stem cells [17]. In-vivo studies on hepatocellular carcinoma xenografts have shown that metformin improves cellular oxygenation ability and decreases mitochondrial oxygen consumption, thus suppressing hypoxia-induced HIF-1 $\alpha$ accumulation. These effects form the basis of anti-cancer activity of metformin, particularly against hepatocellular carcinoma [18].

In addition to the above, various other mechanisms of metformin for cell growth inhibition have been identified in pre-clinical models. Metformin therapy in paired isogenic colon cancer cell lines (HCT116 p53 [+/+] and HCT116 p53 [-/-]) showed an increase in apoptosis of p53 deficient cells [19]. In-vitro and in-vivo analysis of metformin therapy showed that it can inhibit growth of ovarian stem cells [20], glioma initiating cells [21], breast cancer cells [22], endometrial cancer cells [23] and non-small cell lung cancer cells [24]. It has also exhibited synergistic action with VEGF inhibitors to inhibit proliferation of BRAF mutant melanoma cells [25]. Additionally, it has been noted that metformin increases radiosensitivity of cancer cells [22, 24].

Recent experiments on animal models have also suggested that metformin has immune modulatory properties. Metformin inhibits immune exhaustion of CD8+ tumor induced lymphocytes (TIL), thereby enhancing $\mathrm{T}$ cell mediated immune response to tumor tissue. It decreases apoptosis of CD8+ tumor infiltrating lymphocytes (TILs), and also shifts the phenotype of CD8+ TILs expressing exhaustion markers (especially PD1 negative Tim 3 positive) from central memory $\mathrm{T}$ cells (TCM, inactive against tumor cells) to effector memory T cells (TEM, active against tumor cells). The increase in TEM cell population has been found to correlate with regression of tumor cells [26]. In a study evaluating an experimental cancer vaccine, administration of metformin after vaccination in animal models showed an increase in $\mathrm{CD} 8+$ memory $\mathrm{T}$ cells which conferred protective immunity upon subsequent tumor challenge [27]. Figure 1 summarizes the effects of metformin on various cellular pathways.

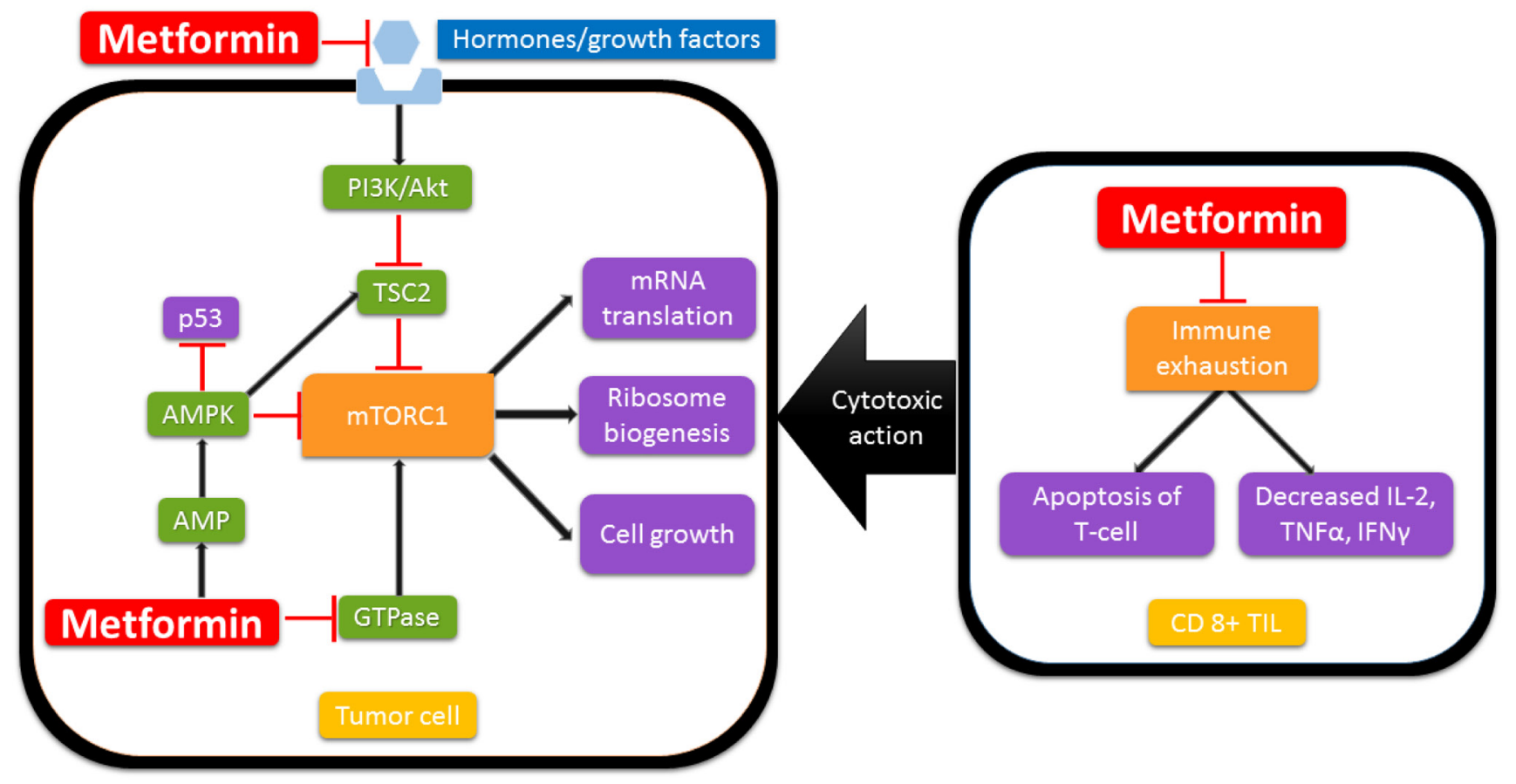

Figure 1: Possible mechanisms of anti-cancer activity of metformin. The inhibition of mTORC1 is mediated by reducing the downstream effects of IGF-1 and insulin hormone receptor binding, increased TSC2 phosphorylation by AMPK, Rag GTPase mediated inhibition and phosphorylation of mTOR binding raptor by AMPK. This leads to inhibition of mRNA translation, ribosomal biogenesis and cell growth. Metformin also potentiates the immune system by reducing immune exhaustion of CD 8+ tumor infiltrating lymphocytes through phenotypic switching to memory cells, thus enhancing the immune response to cancer cells. Abbreviations: AMP, Adenosine monophosphate; AMPK, AMP activated protein kinase; GTPase, Ras-related GTPase; mTORC1, Mammalian receptor of rapamycin; TSC2, Tuberous sclerosis complex protein 2; PI3K, Phosphoinositide 3 kinase; Akt, Protein kinase B; IL-2, Interleukin-2; TNFa, Tumor necrosis factor $-\alpha$; IFN $\gamma$, Interferon $\gamma$ 
Table 2: Anti-tumor activity of metformin in locally advanced and hematologic cancers

\begin{tabular}{|c|c|c|c|c|c|c|c|c|}
\hline Cancer type & Phase & $\begin{array}{l}\text { Primary outcome/ } \\
\text { Conclusion }\end{array}$ & Dosing regimen & Combination & $\begin{array}{l}\text { Enrollment } \\
\text { No. }\end{array}$ & Status & Results & $\begin{array}{l}\text { Clinical trial } \\
\text { identifier/ } \\
\text { Reference }\end{array}$ \\
\hline AML & Phase I & $\begin{array}{l}\text { MTD of metformin } \\
\text { plus cytarabine }\end{array}$ & $\begin{array}{l}\text { Metformin PO BID on days 1-15 and cytarabine IV } \\
\text { over } 3 \text { hours BID on days 4-10. }\end{array}$ & $\begin{array}{l}\text { metformin, } \\
\text { cytarabine }\end{array}$ & 28 & Recruiting & NA & NCT01849276 \\
\hline Breast & $\begin{array}{l}\text { Phase II } \\
\text { RCT }\end{array}$ & $\begin{array}{lr}\mathrm{pCR} & \text { rate } \\
\text { (evaluated in } & 5 \\
\text { months) }\end{array}$ & $\begin{array}{l}\text { Docetaxel } 75 \mathrm{mg} / \mathrm{m}^{2} \mathrm{IV} \text {, epirubicin } 75 \mathrm{mg} / \mathrm{m}^{2} \mathrm{IV} \text { and } \\
\text { cyclophosphamide } 500 \mathrm{mg} / \mathrm{m}^{2} \text { IV day } 1 \text { of each } 21 \\
\text { day cycle; } 6 \text { cycles; metformin } 500 \mathrm{mg} \text { TID PO } \\
\text { (500mg daily in } 1 \mathrm{st} \text { cycle) }\end{array}$ & $\begin{array}{l}\text { metformin, } \\
\text { docetaxel, } \\
\text { epirubicin, } \\
\text { cyclophosphamide }\end{array}$ & 200 & Recruiting & NA & NCT01929811 \\
\hline Breast & $\begin{array}{l}\text { Phase II } \\
\text { RCT }\end{array}$ & $\begin{array}{l}\text { Clinical response } \\
\text { rate }\end{array}$ & $\begin{array}{l}\text { Letrozole } 2.5 \mathrm{mg} \text { PO daily, metformin } 500 \mathrm{mg} \text { BID } \\
\text { PO daily x 1week; metformin } 1000 \mathrm{mg}(\mathrm{am}) \& 500 \\
\mathrm{mg}(\mathrm{pm}) \text { PO daily x 1week; metformin 1000mg BID } \\
\text { PO daily x } 22 \text { weeks }\end{array}$ & $\begin{array}{l}\text { metformin, } \\
\text { letrozole }\end{array}$ & 208 & Recruiting & NA & NCT01589367 \\
\hline Breast & $\begin{array}{l}\text { Phase II } \\
\text { RCT }\end{array}$ & $\begin{array}{l}\text { To evaluate if using } \\
\text { new chemotherapy } \\
\text { drugs with standard } \\
\text { neoadjuvant } \\
\text { chemotherapy } \\
\text { agents increases } \\
\text { pCR. }\end{array}$ & $\begin{array}{l}\text { AMG } 479 \text { (Ganitumab) } 12 \mathrm{mg} / \mathrm{kg} \text { IV every } 2 \text { weeks } \\
\text { during } 12 \text { week cycle }+ \text { metformin } 850 \mathrm{mg} \text { PO every } \\
\text { week during } 12 \text { weekly cycles post-randomization }\end{array}$ & $\begin{array}{l}\text { metformin, } \\
\text { ganitumab }\end{array}$ & 800 & Recruiting & NA & NCT01042379 \\
\hline Breast & $\begin{array}{ll}\text { Phase } & \text { III } \\
\text { RCT }\end{array}$ & $\begin{array}{l}\text { Invasive disease- } \\
\text { free survival }\end{array}$ & $\begin{array}{l}\text { Metformin HCl PO BID (QD for first } 4 \text { weeks), for } \\
\text { up to } 5 \text { years. }\end{array}$ & $\begin{array}{l}\text { metformin } \\
\text { monotherapy }\end{array}$ & 3649 & $\begin{array}{l}\text { Active but not } \\
\text { recruiting }\end{array}$ & NA & NCT01101438 \\
\hline Breast & $\begin{array}{l}\text { Phase III } \\
\text { RCT }\end{array}$ & $\begin{array}{l}\text { Evaluating atypia } \\
\text { after } 12 \text { and } \\
24 \text { months of } \\
\text { metformin }\end{array}$ & $\begin{array}{l}\text { Metformin } \mathrm{HCl} 850 \mathrm{mg} \text { PO BID for } 24 \text { months } \\
\text { on arm 1, including } 4 \text { weeks escalation dosing } \\
\text { of } 850 \mathrm{mg} \text { PO QD. Patients initially randomized } \\
\text { to the placebo arm (Arm 2) may crossover to the } \\
\text { metformin arm (Arm 1) for months 13-24. }\end{array}$ & $\begin{array}{l}\text { metformin } \\
\text { monotherapy }\end{array}$ & 400 & $\begin{array}{l}\text { Not yet } \\
\text { recruiting }\end{array}$ & NA & NCT01905046 \\
\hline $\begin{array}{l}\text { Chronic } \\
\text { Lymphocytic } \\
\text { Leukemia }\end{array}$ & Phase II & $\begin{array}{l}\text { Time to treatment } \\
\text { failure (assessed } \\
\text { every } 3 \text { months) }\end{array}$ & $\begin{array}{l}\text { Initial dose of metformin will be } 500 \mathrm{mg} \text { PO QD for } \\
1 \text { week, escalated to } 500 \mathrm{mg} \text { BID after } 1 \text { week, and } \\
\text { finally to } 1000 \mathrm{mg} \text { BID in week } 3 \text { if tolerated. }\end{array}$ & $\begin{array}{l}\text { metformin } \\
\text { monotherapy }\end{array}$ & 53 & Recruiting & NA & NCT01750567 \\
\hline Colorectal & Phase II & $\begin{array}{l}\text { Disease Control } \\
\text { Rate (assessed up } \\
\text { to } 1 \text { year) }\end{array}$ & FOLFOX6+Metformin or FOFIRI + Metformin & $\begin{array}{l}\text { metformin, } \\
\text { FOLFOX6, } \\
\text { FOFIRI }\end{array}$ & 48 & Recruiting & NA & NCT01926769 \\
\hline Endometrial & Phase II & CBR & $\begin{array}{l}\text { Metformin } 500 \mathrm{mg} \text { PO QD for days } 1-4 \text { of cycle } 0 \\
\text { and then BID after that. Metformin to be taken for } \\
7-10 \text { days in cycle } 0 \text { before cycle } 1 \text { begins; letrozole } \\
2.5 \mathrm{mg} \text { PO QD in a } 28 \text { day cycle; everolimus } 10 \mathrm{mg} \\
\text { PO QD in a } 28 \text { day cycle. }\end{array}$ & $\begin{array}{l}\text { metformin, } \\
\text { letrozole, } \\
\text { everolimus }\end{array}$ & 64 & Recruiting & NA & NCT01797523 \\
\hline Endometrial & $\begin{array}{l}\text { Phase II } \\
\text { RCT }\end{array}$ & \begin{tabular}{lr|} 
Pathological & \\
response & rate \\
(evaluated at 12 \\
weeks)
\end{tabular} & $\begin{array}{l}\text { Metformin } 500 \mathrm{mg} \text { PO third daily and megestrol } \\
\text { acetate } 150 \mathrm{mg} \text { PO QD for } 3 \text { months }\end{array}$ & $\begin{array}{l}\text { metformin, } \\
\text { megestrol acetate }\end{array}$ & 150 & Recruiting & NA & NCT01968317 \\
\hline Endometrial & $\begin{array}{l}\text { Phase II, } \\
\text { III RCT }\end{array}$ & $\begin{array}{l}\text { PFS (Phase II) } \\
\text { (assessed up to } 5 \\
\text { years) }\end{array}$ & $\begin{array}{l}\text { Day 1- paclitaxelIV over } 3 \text { hours and carboplatin } \\
\text { IV; metformin PO BID on days } 1-21 \text { (QD in } \\
\text { cycle 1). Treatment repeats every } 21 \text { days for } 6 \\
\text { cycles. Patients then receive maintenance therapy- } \\
\text { metformin PO BID on days } 1 \text { - } 21 \text {. Course repeated } \\
\text { every } 21 \text { days. }\end{array}$ & $\begin{array}{l}\text { metformin, } \\
\text { paclitaxel, } \\
\text { carboplatin }\end{array}$ & 540 & Recruiting & $\mathrm{NA}$ & NCT02065687 \\
\hline $\begin{array}{l}\text { Glioblastoma } \\
\text { Multiforme }\end{array}$ & Phase I & $\begin{array}{l}\text { MTD and PFS } \\
\text { assessed at } 6 \\
\text { months }\end{array}$ & $\begin{array}{l}\text { Temozolomide } 150 \mathrm{mg} / \mathrm{m}^{2} \text { PO on alternate weeks } \\
\text { days } 1-7,15-21 \text { of a } 28 \text { day cycle; metformin } 1000 \\
\mathrm{mg} \text { PO BID for } 28 \text { day cycle. }\end{array}$ & $\begin{array}{l}\text { metformin, } \\
\text { temozolomide }\end{array}$ & 144 & Recruiting & $\mathrm{NA}$ & NCT01430351 \\
\hline Lung & Phase II & $\begin{array}{l}\text { PFS (assessed for } \\
\text { up to } 52 \text { weeks) }\end{array}$ & $\begin{array}{l}\text { Metformin } 1000 \mathrm{mg} \text { PO BID added to standard of } \\
\text { care platinum based chemotherapy }\end{array}$ & metformin, & 60 & Recruiting & $\mathrm{NA}$ & NCT02019979 \\
\hline Lung & $\begin{array}{l}\text { Phase II } \\
\text { RCT }\end{array}$ & $\begin{array}{l}\text { PFS assessed at } \\
1 \text { year }\end{array}$ & $\begin{array}{l}\text { Gefitinib + metformin; metformin starting at } 500 \\
\mathrm{mg} \text { TID PO. After } 1 \text { week, increase dose to } 1000 \\
\mathrm{mg} \text { as the } 1 \text { st dose of the day and } 500 \mathrm{mg} \text { as the } \\
2^{\text {nd }} \text { dose. After another week, increase to } 1000 \mathrm{mg} \\
\text { TID. Metformin treatment will be initiated } 1 \text { week } \\
\text { before TKI therapy if possible. }\end{array}$ & $\begin{array}{l}\text { chemonerapy } \\
\text { metformin, } \\
\text { gefitinib }\end{array}$ & 168 & Recruiting & $\mathrm{NA}$ & NCT01864681 \\
\hline Ovary & Phase 1 & $\begin{array}{l}\text { Assess safety and } \\
\text { tolerability of the } \\
\text { treatment }\end{array}$ & $\begin{array}{l}\text { Escalating doses of metformin will be added to } \\
\text { carboplatin IV / paclitaxel IV chemotherapy for } \\
\text { up to } 6 \text { cycles. }\end{array}$ & $\begin{array}{l}\text { metformin, } \\
\text { carboplatin, } \\
\text { paclitaxel }\end{array}$ & 20 & $\begin{array}{l}\text { Not yet } \\
\text { recruiting }\end{array}$ & $\mathrm{NA}$ & NCT02312661 \\
\hline $\begin{array}{l}\text { Ovarian, } \\
\text { Fallopian } \\
\text { Tube or } \\
\text { Primary }\end{array}$ & Phase 1 & $\begin{array}{l}\text { Success rates of } \\
\text { the combination } \\
\text { chemotherapy }\end{array}$ & $\begin{array}{l}\text { Day 1- paclitaxel IV over } 3 \text { hours, carboplatin } \\
\text { IV, metformin HCl BID on days } 1-21 \text {; treatment } \\
\text { repeated every } 21 \text { days for } 6 \text { cycles }\end{array}$ & $\begin{array}{l}\text { metformin, } \\
\text { paclitaxel, } \\
\text { carboplatin }\end{array}$ & 18 & $\begin{array}{l}\text { Not yet } \\
\text { recruiting }\end{array}$ & $\mathrm{NA}$ & NCT02050009 \\
\hline Pancreas & Phase II & $\begin{array}{ll}\text { PFS at } 12 \\
\text { months }\end{array}$ & Everolimus + octreotide LAR + metformin & $\begin{array}{l}\text { metformin, } \\
\text { everolimus, } \\
\text { octreotide LAR }\end{array}$ & 43 & Recruiting & NA & NCT02294006 \\
\hline Pancreas & $\begin{array}{l}\text { Phase II } \\
\text { RCT }\end{array}$ & $\begin{array}{l}\text { RFS after } \\
\text { surgery (assessed } \\
\text { every } 2 \text { months } \\
\text { during treatment } \\
\text { and every } 3 \\
\text { months after } \\
\text { completion, till } \\
24 \text { months) }\end{array}$ & $\begin{array}{l}\text { Metformin } 500 \mathrm{mg} \text { BID initially, if tolerated, } \\
\text { dose to be increased to } 1000 \mathrm{mg} \text { BID in the } 2^{\text {nd }} \\
\text { week; gemcitabine } 1000 \mathrm{mg} / \mathrm{m}^{2} \text { (IV, } 30 \text { minutes) } \\
\text { on days } 1,8 \text {, and } 15 \text { for } 3 \text { weeks, followed by } 1 \\
\text { week without treatment, and also receive placebo } \\
\text { (Arm I)/ metformin (Arm II) on days } 1-28 \text {. Course } \\
\text { repeated every } 4 \text { weeks for up to } 6 \text { cycles. }\end{array}$ & $\begin{array}{l}\text { metformin, } \\
\text { gemcitabine }\end{array}$ & 300 & Recruiting & NA & NCT02005419 \\
\hline Prostate & Phase I & $\begin{array}{l}\text { DLT assessed at } \\
28 \text { days }\end{array}$ & $\begin{array}{l}\text { Enzalutamide POQD and metformin HCIPO BID. } \\
\text { Courses repeat every } 28 \text { days }\end{array}$ & $\begin{array}{l}\text { metformin, } \\
\text { enzalutamide }\end{array}$ & 24 & $\begin{array}{l}\text { Not yet } \\
\text { recruiting }\end{array}$ & $\mathrm{NA}$ & NCT02339168 \\
\hline
\end{tabular}




\begin{tabular}{|c|c|c|c|c|c|c|c|c|}
\hline Solid tumors & Phase I & $\begin{array}{l}\text { To evaluate DLT } \\
\text { when metformin } \\
\text { is added to a } \\
\text { chemotherapy } \\
\text { regimen that is } \\
\text { well tolerated. }\end{array}$ & $\begin{array}{l}\text { Stage 1- patients randomized to } 2 \text { arms- concurrent } \\
\text { arm (metformin + chemo) and delayed arm (chemo } \\
\text { alone). Stage 2- patients in delayed arm crossed } \\
\text { over to concurrent arm; metformin dose- 500mg } \\
\text { BID + chemotherapy }\end{array}$ & $\begin{array}{l}\text { metformin, } \\
\text { chemotherapy }\end{array}$ & 100 & Completed & $\begin{array}{l}\text { Metformin plus } \\
\text { chemotherapy had } \\
\text { a lower rate of } \\
\text { DLTs (6.1\%) as } \\
\text { compared to those } \\
\text { who received only } \\
\text { chemotherapy } \\
(7.8 \%) \text {; Patients } \\
\text { showing DLT with } \\
\text { metformin included } \\
\text { the ones already } \\
\text { known to have } \\
\text { adverse effects } \\
\text { with chemotherapy; } \\
\text { Post-treatment with } \\
\text { metformin, AMPK } \\
\text { phosphorylation } \\
\text { increased by 4-6 } \\
\text { folds, 46\% showed } \\
\text { stable disease } \\
\text { and } 28 \% \text { of the } \\
\text { patients who had } \\
\text { quantifiable tumor } \\
\text { markers showed } \\
\text { favorable changes. }\end{array}$ & $\begin{array}{l}\text { NCT01442870 } \\
{[49]}\end{array}$ \\
\hline Uterus & $\begin{array}{l}\text { Phase II } \\
\text { RCT }\end{array}$ & $\begin{array}{l}\text { pCR (assessed } \\
\text { at } 6 \text { months) }\end{array}$ & $\begin{array}{l}\text { Metformin } 500 \mathrm{mg} \text { BID PO + levonorgestrel } 52 \mathrm{mg} \\
\text { IUD for } 6 \text { months }\end{array}$ & $\begin{array}{l}\text { metformin, } \\
\text { levonorgestrel }\end{array}$ & 165 & Recruiting & NA & NCT01686126 \\
\hline
\end{tabular}

Abbreviations: RFS, recurrence free survival; PFS, Progression free survival; DLT, dose limiting toxicity; MTD, Maximum tolerable dose; pCR, Pathological complete response; RCT, Randomized control trial; CBR, Clinical benefit rate; IHC, immunohistochemistry; HOMA, Homeostasis model assessment; CI, Confidence interval; PO, taken by mouth; QD, once a day; BID, two times a day; TID, three times a day; IUD, Intra-uterine device

\section{EPIDEMIOLOGY}

There are numerous epidemiological studies that have put forth evidence suggesting utility of metformin as an anti-cancer agent.

Several observational and cohort studies have been conducted to assess the influence of metformin on cancer. Survival analysis in a cohort study on diabetic patients comparing metformin users $(n=4,085)$ to non-users ( $n$ $=4,085$ ) reported a reduced risk of cancer (hazard ratio, $\mathrm{HR}=0.63 ; 7.3 \%$ diagnosed with cancer in metformin users versus $11.6 \%$ in non-users) [28]. Meta-analysis performed on 37 studies, with a total of 1,535,636 patients comparing metformin users and non-users reported overall cancer incidence summary relative risk (SRR) as 0.73 . The results also noted a reduction of cancer incidence for liver $(78 \%)$, breast $(6 \%)$, pancreatic $(46 \%)$ and colorectal cancer $(23 \%)$. However, no significant correlation could be derived between the use of metformin and incidence of prostate cancer [29]. Meta-analysis of 6 case control studies comparing 39,787 participants that were on metformin to 177,752 participants that were not, exhibited a lower risk of developing lung cancer in the metformin group (odds ratio, $\mathrm{OR}=0.55 ; p<0.001$ ) [30]. Likewise, another meta-analysis showed a reduction in incidence of prostate cancer $(\mathrm{RR}=0.88 ; p=0.03)$ in patients who were on metformin treatment [31]. Meta-analysis of 35 observational studies reported a considerable correlation with using metformin to reduce the risk of developing allcancer $(\mathrm{OR}=0.73)$, liver cancer $(\mathrm{OR}=0.34)$, colorectal cancer $(\mathrm{OR}=0.83)$, pancreatic cancer $(\mathrm{OR}=0.56)$, gastric cancer $(\mathrm{OR}=0.83)$, and esophageal cancer $(\mathrm{OR}=0.90)$ [32]. A recent meta-analysis of 265 studies showed the use of metformin or thiazolidinediones was associated with a lower incidence of cancer $(\mathrm{RR}=0.86$ and 0.93 respectively). But interestingly, insulin, sulfonylureas, and alpha glucosidase inhibitor use was associated with an increased incidence of cancer $(\mathrm{RR}=1.21,1.20,1.10$ respectively) [33].

Meta-analysis of retrospective studies has provided substantial evidence associating the use of metformin with a decrease in cancer related mortality. A cohort study, investigating mortality due to cancer in type 2 diabetes patients, showed a decrease in cancer related mortality risk $(\mathrm{HR}=0.56)$ with the use of metformin [34]. Data from meta-analysis of 6 observational studies noted a significant correlation between using metformin and risk of cancer related mortality $(\mathrm{OR}=0.65)$ [32]. Retrospective analysis of data from over 350 primary care practices in the United Kingdom found a decrease in cancer related mortality $(\mathrm{HR}=0.85)$ in diabetic patients who were on metformin monotherapy when compared with those on other drugs for diabetes [35]. Another meta-analysis showed that the use of metformin in diabetic patients diagnosed with cancer was associated with a decrease in risk of allcause mortality in cancers of breast (pooled relative risk, $\mathrm{RR}=0.70 ; p=0.003)$, ovary $(\mathrm{RR}=0.44 ; p<0.001)$, endometrium $(\mathrm{RR}=0.49 ; p=0.001)$ and colorectal cancer $(\mathrm{RR}=0.70 ; p<0.001)$ [36].

In light of the available preclinical and retrospective data suggesting anti-cancer properties of metformin, clinical trials are necessary to further investigate its role in cancer therapy.

\section{METHODS}

Information about the study drug was obtained from clinicaltrials.gov (a service of United States National Institutes of Health), using the search query "metformin" and "cancer". Of the 223 results obtained from the search engine, relevant drug trials were selected. The published clinical trials were obtained from PubMed using the same search query and choosing the "clinical trial" filter. The publications that focused on use of metformin 
for treatment of cancer in human subjects through a prospective clinical trial were identified and selected. The results of completed clinical trials were obtained from PubMed and online abstract library for professional societies such as the American Association of Cancer Research (AACR) and American Society of Clinical Oncology (ASCO). The AACR and ASCO online libraries were explored using the NCT number associated with the clinical trial. The authors, enrollment number, primary \& secondary outcomes and primary location of conducting the research mentioned in abstracts collected from ASCO and AACR database were matched with the information obtained from clinicaltrials.gov to avoid any discrepancies in associating the abstracts to the appropriate trial.

\section{CLINICAL TRIALS}

Presently, there are 55 ongoing clinical trials in various stages that are evaluating metformin as a monotherapy (11 trials, $20 \%$ of all ongoing trials using metformin as an anti-cancer agent) or in combination with cytotoxic chemotherapy (38 trials, 69\%) and/or radiotherapy (6 trials, 11\%) for the treatment of cancer (Tables 1-4). These trials primarily focus on establishing the effects of metformin on markers of cellular proliferation, pathological response rate, progression free survival, and recurrence free survival. Also, certain trials are directed towards determining the maximum tolerable dose of metformin in specific tumors.

A considerable amount of focus has been laid on investigating metformin as a potential anti-cancer agent for cases of breast cancer. Eleven trials (20\% of all ongoing trials using metformin as an anti-cancer agent; Tables 1-3) are focused on evaluating metformin as a treatment for breast cancer. Of these, two trials are using metformin as monotherapy. There are 9 trials using metformin in combination with other anti-cancer agents. These include capecitabine, cyclophosphamide, docetaxel, doxorubicin, erlotinib, epirubicin, exemestane, ganitumab, letrozole, sirolimus and temsirolimus. One trial is exploring the use of metformin plus atorvastatin combination as a possible treatment for breast cancer. Two trials using metformin combination therapy are also evaluating pathological complete response as a primary endpoint. Apart from the ongoing trials, data obtained from 5 completed trials (all using metformin monotherapy in a pre-surgical window of opportunity trial design) has facilitated a better understanding regarding the effects of metformin in breast cancer. In addition to survival outcomes, several surrogate markers are also being employed to study the effects of metformin on breast cancer cell population. These include Ki67, S6K, 4E-BP-1, AMPK and effects on AMPK/mTOR pathway.

A phase 2 single arm window of opportunity trial of 39 breast cancer cases [37] showed significant reduction in $\mathrm{Ki} 67$ (36.5 to $33.5 \%, p=0.016$ ) and an increase in
TUNEL staining ( 0.56 to $1.05, p=0.004)$ along with significant fall in HOMA (homeostatic model assessment, used for determining the status of insulin resistance) [38]. A recently published randomized control trial (RCT) also reported a decrease in Ki67 staining (mean $=3.4 \%$, $p=0.027$ ). Additionally, it noted an increase in mean AMPK score, fall in pAKT score and reduced caspase- 3 staining in patient samples with the use of metformin when compared to placebo [39]. However, other trials have had conflicting outcomes. A phase II RCT with 200 participants recorded no significant changes in Ki67 on comparing metformin and placebo arms. But, interestingly, the cases with HOMA $\leq 2.8$ showed a nonsignificant increase of Ki67 by $11.1 \%$ (95\% Confidence interval (CI): $-0.6 \%$ to $24.2 \%$ ) and those with HOMA > 2.8 (implying a higher probability of insulin resistance) showed a non-significant mean proportional decrease in Ki67 by $10.5 \%$ (95\% CI: $-26.1 \%$ to $8.4 \%$ ) [40]. Another phase II trial (non-randomized) examined effects of metformin in overweight/obese patients with stage 0 -III breast cancer. Though noting a correlation of Ki67 with tumor growth, the calculated ln (Ki67) showed no significant changes when comparing metformin to placebo [41]. A different study with 200 participants randomized to metformin or placebo did not document any major difference in Ki67 and TUNEL levels (used for assessing cellular apoptosis) between the two arms. The study did note that TUNEL levels were higher in women without insulin resistance (metformin: $+4 \%$, interquartile range, IQR: $2-14$, placebo: $+2 \%$, IQR: $0-7$ ) as compared to those who had insulin resistance (metformin $+2 \%$, IQR: $0-6$, placebo $+5 \%$, IQR: 0-15) [42]. The survival benefit with the use of metformin in breast cancer is being evaluated in 3 clinical trials, however there is no data presently available (NCT01627067, NCT0131023, NCT01885013).

Metformin is presently being evaluated as an anti-cancer agent for endometrial cancer as well. There are 6 ongoing trials $(10.9 \%$ of all ongoing trials using metformin as an anti-cancer agent; Tables 1, 2), with 3 each for monotherapy and combination chemotherapy. The drugs that are currently being assessed in combination with metformin for treatment of endometrial cancer are carboplatin, everolimus, letrozole, paclitaxel, and megestrol acetate. One trial is assessing the role of metformin as a maintenance therapy. In conjunction with clinical response, the effect of metformin on endometrial cancer is being studied through a wide variety of markers including Ki67, pS6, Akt, pAMPK, ERK1/2, histone $\mathrm{H} 3$, telomerase, topoisomerase II $\alpha$ and $\mathrm{p} 27$. The effect of using metformin on expression of estrogen (ER) and progesterone (PR) receptors in cancer tissue of endometrial origin is also being investigated. Three completed trials, all pre-surgical window of opportunity trials using metformin monotherapy, have shown a significant decrease in Ki67 staining [43-45] and in pS6 staining $[44,45]$. One trial also reported a reduction in 
Table 3: Anti-tumor activity of metformin in metastatic tumors

\begin{tabular}{|c|c|c|c|c|c|c|c|c|}
\hline Cancer type & Phase & $\begin{array}{l}\text { Primary outcome/ } \\
\text { Conclusion }\end{array}$ & Dosing regimen & Combination & $\begin{array}{l}\text { Enrollment } \\
\text { No. }\end{array}$ & Status & Results & $\begin{array}{l}\text { Clinical trial } \\
\text { identifier/ } \\
\text { Reference }\end{array}$ \\
\hline Breast & Phase I & $\begin{array}{l}\text { MTD of metformin when } \\
\text { used with erlotinib }\end{array}$ & $\begin{array}{l}\text { Initial metformin dose will be } 850 \mathrm{mg} \text { BID } \\
\text { and escalated to maximum FDA approved } \\
\text { dose of } 850 \mathrm{mg} \text { TID. DLT will be determined } \\
\text { during the first } 5 \text { weeks of therapy; erlotinib } \\
150 \mathrm{mg} \text { daily. }\end{array}$ & metformin, erlotinib & 20 & Recruiting & NA & \\
\hline Breast & Phase II & PFS assessed at 2 months & $\begin{array}{l}\text { Exemestane } 25 \mathrm{mg} \text { PO QD, everolimus } 10 \\
\mathrm{mg} \text { PO daily and metformin } 500 \mathrm{mg} \text { PO daily } \\
\text { for } 3 \text { days. If DLT does not occur, metformin } \\
\text { dose will be escalated by } 500 \mathrm{mg} \text { PO every } \\
3 \text { days to reach target of } 1000 \mathrm{mg} \text { PO BID }\end{array}$ & $\begin{array}{l}\text { metformin, } \\
\text { exemestane }\end{array}$ & 40 & $\begin{array}{l}\text { Active } \\
\text { but not } \\
\text { recruiting }\end{array}$ & NA & NCT01627067 \\
\hline Breast & $\begin{array}{l}\text { Phase II } \\
\text { RCT }\end{array}$ & $\begin{array}{l}\text { PFS (assessed up to } 3 \\
\text { years) }\end{array}$ & $\begin{array}{l}\text { Metformin } 850 \mathrm{mg} \text { BID in addition } \\
\text { to standard chemotherapy consisting } \\
\text { anthracyclines, platinum, taxanes or } \\
\text { capecitabine }\end{array}$ & $\begin{array}{l}\text { metformin, standard } \\
\text { chemotherapy } \\
\text { (anthracycline, } \\
\text { platinum, taxanes } \\
\text { or capecitabine) } \\
\end{array}$ & 78 & Recruiting & NA & NCT01310231 \\
\hline Breast & $\begin{array}{ll}\text { Phase } & \text { II } \\
\text { RCT } & \end{array}$ & $\begin{array}{l}\text { PFS (assessed up to } 42 \\
\text { months) }\end{array}$ & $\begin{array}{l}\text { Cycle 1- ONLY metformin from day } 1-13, \\
\text { chemotherapy initiated from day } 14 \text {; day } 1-3- \\
\text { metformin } 1000 \mathrm{mg} \text { QD, day } 4 \text { - metformin } \\
1000 \mathrm{mg} \text { BID; Myocet } 60 \mathrm{mg} / \mathrm{m} 2 \text { IV on day } \\
1 \text {, every } 21 \text { days; Cyclophosphamide } 600 \mathrm{mg} / \\
\mathrm{m}^{2} \mathrm{IV} \text { at day } 1 \text { every } 21 \text { days }\end{array}$ & $\begin{array}{l}\text { metformin, myocet, } \\
\text { cyclophosphamide }\end{array}$ & 112 & Recruiting & NA & NCT01885013 \\
\hline Colorectal & Phase II & $\begin{array}{l}\text { Progression assessed at } \\
12 \text { weeks }\end{array}$ & $\begin{array}{l}\text { Irinotecan } 350 \mathrm{mg} / \mathrm{m}^{2} \mathrm{q} 21 \mathrm{~d}+\text { metformin up } \\
\text { to } 2500 \mathrm{mg} / \mathrm{day}\end{array}$ & $\begin{array}{l}\text { metformin, } \\
\text { irinotecan }\end{array}$ & 41 & $\begin{array}{l}\text { Not yet } \\
\text { recruiting }\end{array}$ & NA & NCT01930864 \\
\hline Colorectal & Phase II & $\begin{array}{l}\text { Disease control rate } \\
\text { (assessed every } 8 \text { weeks) }\end{array}$ & $\begin{array}{l}\text { metformin } 850 \mathrm{mg} \text { PO BID plus } 5 \mathrm{FU} 425 \mathrm{mg} / \\
\mathrm{m} 2 \text { plus leucovorin } 50 \mathrm{mg} \text { IV weekly }\end{array}$ & $\begin{array}{l}\text { metformin, } 5 \mathrm{FU}, \\
\text { leucovorin }\end{array}$ & 50 & Recruiting & NA & NCT01941953 \\
\hline Lung & $\begin{array}{l}\text { Phase II } \\
\text { RCT }\end{array}$ & $\begin{array}{l}\text { PFS (assessed at 1 } \\
\text { year) of metformin plus } \\
\text { standard chemotherapy }\end{array}$ & $\begin{array}{l}\text { Metformin started at } 500 \mathrm{mg} \text { BID PO. Dose } \\
\text { increased to } 1000 \mathrm{mg} \text { as } 1^{\text {st }} \text { dose and } 500 \\
\mathrm{mg} \text { as } 2^{\text {nd }} \text { dose of the day after } 1 \mathrm{st} \text { week. } \\
\text { After another week, dose will be } 1000 \mathrm{mg} \\
\text { BID. Metformin initiated } 1 \text { week before } \\
\text { chemotherapy. Paclitaxel } 200 \mathrm{mg} / \mathrm{m}^{2} \mathrm{IV} \text {, } \\
\text { day } 1 \text { of each cycle. Carboplatin at AUC }= \\
6 \mathrm{mg} / \mathrm{ml} \mathrm{IV} \text { following paclitaxel, every } 21 \\
\text { days. Bevacizumab } 15 \mathrm{mg} / \mathrm{kg} \text { every } 21 \\
\text { days, after completion of chemotherapy, } \\
\text { starting with cycle } 1 \text {. After } 4 \text { cycles } \\
\text { of induction chemotherapy, continue } \\
\text { bevacizumab at } 15 \mathrm{mg} / \mathrm{kg} \text { every } 21 \text { days } \\
\text { until disease progression. }\end{array}$ & $\begin{array}{l}\text { metformin, } \\
\text { paclitaxel, } \\
\text { bevacizumab, } \\
\text { carboplatin }\end{array}$ & 60 & Recruiting & NA & NCT01578551 \\
\hline Melanoma & Phase II & $\begin{array}{l}\text { RR defined by the ratio } \\
\text { between total number } \\
\text { of patients with a } \\
\text { complete response } \\
\text { (CR) or partial } \\
\text { response (PR). }\end{array}$ & $2540 \mathrm{mg} /$ day of metformin-base & $\begin{array}{l}\text { metformin } \\
\text { monotherapy }\end{array}$ & 20 & Unknown & NA & NCT01840007 \\
\hline Melanoma & $\begin{array}{l}\text { Phase II } \\
\text { RCT }\end{array}$ & $\mathrm{RR}$ & $\begin{array}{l}\text { Dacarbazine } 1000 \mathrm{mg} / \mathrm{m}^{2} \text { once every } 28 \\
\text { days with Metformin } 850 \mathrm{mg} \text { BID }\end{array}$ & $\begin{array}{l}\text { metformin, } \\
\text { dacarbazine }\end{array}$ & 96 & Recruiting & NA & NCT02190838 \\
\hline Neuro-endocrine & Phase II & $\begin{array}{l}\text { Disease free survival } \\
\text { (assessed at } 180 \text { days) }\end{array}$ & Metformin 850mg BID & $\begin{array}{l}\text { metformin } \\
\text { monotherapy }\end{array}$ & 30 & Recruiting & NA & NCT02279758 \\
\hline $\begin{array}{l}\text { Ovarian, } \\
\text { fallopian tube, } \\
\text { or primary } \\
\text { peritoneal cancer }\end{array}$ & $\begin{array}{l}\text { Phase II } \\
\text { RCT }\end{array}$ & PFS & $\begin{array}{l}\text { Chemotherapy options- } 1 \text {. Paclitaxel IV } \\
\text { over } 2-3 \text { hours + carboplatin IV on day } 1 \text {; } \\
2 \text {. Docetaxel IV over } 1 \text { hour + carboplatin } \\
\text { IV on day } 1 ; 3 \text {. Paclitaxel IV on days } \\
1,8 \text {, and } 15+\text { carboplatin IV on day } 1 \text {. } \\
\text { Patients randomized to } 1 \text { of } 2 \text { treatment } \\
\text { arms and will receive metformin PO BID } \\
\text { with chemotherapy for } 6 \text { courses ( } 21 \text { days } \\
\text { cycle). }\end{array}$ & $\begin{array}{l}\text { metformin, } \\
\text { paclitaxel, } \\
\text { carboplatin, } \\
\text { docetaxel }\end{array}$ & 160 & Recruiting & NA & NCT02122185 \\
\hline Pancreas & Phase I & $\begin{array}{l}\text { To evaluate the } \\
\text { toxicity, feasibility } \\
\text { and compliance of } \\
\text { chemotherapy regimen }\end{array}$ & $\begin{array}{l}\text { Gemcitabine } \mathrm{HCl} \text { and paclitaxel albumin- } \\
\text { stabilized nanoparticle formulation IV } \\
\text { on days } 1,8,15 \text {. Patients also receive } \\
\text { metformin PO BID from day (-)6 and } \\
\text { dietary supplement PO BID from day }(-) 3 \text {. } \\
\text { Cycles repeat every } 28 \text { days. }\end{array}$ & $\begin{array}{l}\text { metformin, } \\
\text { gemcitabine, } \\
\text { paclitaxel }\end{array}$ & 21 & $\begin{array}{l}\text { Not yet } \\
\text { recruiting }\end{array}$ & $\mathrm{NA}$ & NCT02336087 \\
\hline Pancreas & $\begin{array}{ll}\text { Phase } & \text { I, } \\
\text { Phase } & \text { II } \\
\text { RCT } & \end{array}$ & $\begin{array}{l}\text { To evaluate feasibility } \\
\text { and safety of metformin } \\
\text { plus rapamycin versus } \\
\text { rapamycin alone after } \\
\text { stabilization of disease } \\
\text { on chemotherapy }\end{array}$ & $\begin{array}{l}\text { Arm A- metformin } 850 \mathrm{mg} \text { PO BID on a } 28 \\
\text { day cycle, Arm B- metformin } 850 \mathrm{mg} \text { PO } \\
\text { BID plus rapamycin } 4 \mathrm{mg} \text { PO QD on a } 28 \\
\text { day cycle. }\end{array}$ & $\begin{array}{l}\text { metformin, } \\
\text { rapamycin }\end{array}$ & 22 & Recruiting & NA & NCT02048384 \\
\hline Pancreas & Phase II & $\begin{array}{l}\text { Radiological evidence } \\
\text { of disease control }\end{array}$ & $\begin{array}{l}\text { Paclitaxel } 80 \mathrm{mg} / \mathrm{m}^{2} \text { IV day } 1,8,15 \\
\text { metformin } 850 \mathrm{mg} \text { PO TID }\end{array}$ & $\begin{array}{l}\text { metformin, } \\
\text { paclitaxel }\end{array}$ & 41 & Completed & 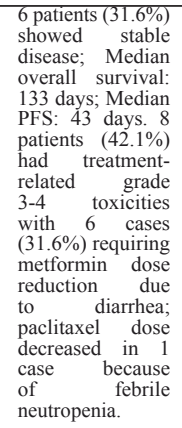 & $\begin{array}{l}\text { NCT01971034 } \\
{[46]}\end{array}$ \\
\hline Pancreas & Phase II & $\begin{array}{l}\text { RR as determined by } \\
\mathrm{CT} / \mathrm{MRI} \text { and PFS }\end{array}$ & $\begin{array}{l}\text { Metformin PO BID days } 1-14 \text { and } \\
\text { FOLFOX therapy comprising leucovorin } \\
\text { calcium IV, fluorouracil IV, and oxaliplatin } \\
\text { IV on day } 1 \text {. Cycles repeated every } 14 \text { days. }\end{array}$ & $\begin{array}{l}\text { metformin, } \\
\text { FOLFOX } \\
\text { (leucovorin } \\
\text { calcium, } \\
\text { fluorouracil, } \\
\text { oxaliplatin) }\end{array}$ & 43 & Recruiting & NA & NCT01666730 \\
\hline
\end{tabular}




\begin{tabular}{|c|c|c|c|c|c|c|c|c|}
\hline Pancreas & $\begin{array}{l}\text { Phase II } \\
\text { RCT }\end{array}$ & PFS at 6 months & $\begin{array}{l}\text { Cisplatin and epirubicin at } 30 \mathrm{mg} / \mathrm{m}^{2} \text { on } \\
\text { days } 1 \text { and } 15 \text {, gemcitabine at } 800 \mathrm{mg} / \mathrm{m}^{2} \\
\text { on days } 1 \text { and } 15 \text {, capecitabine at } 1250 \mathrm{mg} \text { / } \\
\mathrm{m} 2 \text { days } 1-28 \text {, metformin at } 2000 \mathrm{mg} / \mathrm{day} \\
\text { days } 1-28\end{array}$ & $\begin{array}{l}\text { metformin, } \\
\text { cisplatin, } \\
\text { epirubicin, } \\
\text { gemcitabine, } \\
\text { capecitabine }\end{array}$ & 82 & $\begin{array}{l}\text { Active } \\
\text { but not } \\
\text { recruiting }\end{array}$ & NA & NCT01167738 \\
\hline Pancreas & $\begin{array}{l}\text { Phase II } \\
\text { RCT }\end{array}$ & Survival after 6 months & $\begin{array}{l}\text { Gemcitabine } 1000 \mathrm{mg} / \mathrm{m} 2 \text { IV given weekly } \\
\text { for } 3 \text { weeks, followed by } 1 \text { week without } \\
\text { gemcitabine; erlotinib } 100 \mathrm{mg} \text { daily; } \\
\text { metformin } 500 \mathrm{mg} \text { BID, if tolerated, dose } \\
\text { will be increased to } 1000 \mathrm{mg} \text { BID in } 2^{\text {nd }} \\
\text { week. }\end{array}$ & $\begin{array}{l}\text { metformin, } \\
\text { gemcitabine, } \\
\text { erlotinib }\end{array}$ & 120 & Completed & 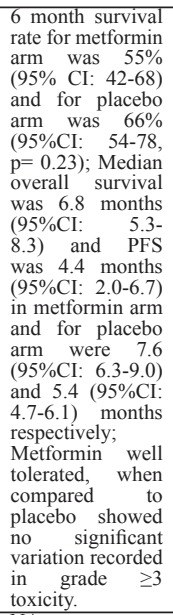 & $\begin{array}{l}\text { NCT01210911 } \\
{[47]}\end{array}$ \\
\hline Prostate & Phase II & $\begin{array}{l}\text { PFS (assessed at } 12 \\
\text { weeks) }\end{array}$ & $\begin{array}{l}\text { Metformin lifelong follow-up at } 1000 \mathrm{mg} \\
\text { BID daily until progression, unacceptable } \\
\text { toxicity or refusal of therapy }\end{array}$ & $\begin{array}{l}\text { metformin } \\
\text { monotherapy }\end{array}$ & 44 & $\begin{array}{l}\text { Active } \\
\text { but not } \\
\text { recruiting }\end{array}$ & NA & NCT01243385 \\
\hline Prostate & Phase II & $\begin{array}{l}\text { PFS (assessed at } 12 \\
\text { weeks) }\end{array}$ & $\begin{array}{l}\text { Addition of metformin } 1000 \mathrm{mg} \text { PO BID } \\
\text { to abiraterone in case of PSA progression }\end{array}$ & $\begin{array}{l}\text { metformin, } \\
\text { abiraterone }\end{array}$ & 25 & Recruiting & NA & NCT01677897 \\
\hline Prostate & $\begin{array}{l}\text { Phase II } \\
\text { RCT }\end{array}$ & PSA response & $\begin{array}{l}\text { Docetaxel } 75 \mathrm{mg} / \mathrm{m}^{2} \text {, metformin } 850 \mathrm{mg} \\
\text { PO BID daily }\end{array}$ & $\begin{array}{l}\text { metformin, } \\
\text { docetaxel }\end{array}$ & 100 & Recruiting & $\mathrm{NA}$ & NCT01796028 \\
\hline $\begin{array}{l}\text { Advanced solid } \\
\text { tumors }\end{array}$ & Phase I & $\begin{array}{l}\text { MTD of metformin } \\
\text { when used in } \\
\text { combination } \\
\text { temsirolimus }\end{array}$ & $\begin{array}{l}\text { Metformin } 500 \mathrm{mg} \text { PO QD/BID/TID daily } \\
\text { on days } 1-28 \text { and temsirolimus } 15-25 \mathrm{mg} \\
\text { IV weekly }\end{array}$ & $\begin{array}{l}\text { metformin, } \\
\text { temsirolimus }\end{array}$ & 11 & Completed & $\begin{array}{c}-3 / 3 \text { patients } \\
\text { in } 1^{\text {st }} \text { cohort } \\
\text { had DLTs } \\
\text { including grade } \\
4 \text { pneumonitis, } \\
\text { grade } 3 \text { fatigue } \\
\text { and grade } 3 \\
\text { thrombocytopenia } \\
-2 / 8 \text { patients had } \\
\text { DLT in } 2^{\text {nd }} \text { cohort: } \\
\text { grade } 4 \text { dyspnea } \\
\text { and grade } 3 \\
\text { thrombocytopenia }\end{array}$ & $\begin{array}{l}\text { NCT00659568 } \\
{[50]}\end{array}$ \\
\hline $\begin{array}{l}\text { Advanced } \\
\text { cancers/ } \\
\text { metastatic } \\
\text { cancers }\end{array}$ & Phase I & $\begin{array}{l}\text { MTD of temsirolimus } \\
\text { and metformin }\end{array}$ & $\begin{array}{l}\text { Temsirolimus } 25 \mathrm{mg} \text { IV weekly; metformin } \\
\text { titrated over } 3 \text { weeks at } 500 \mathrm{mg} \text { PO daily. } \\
4 \text { weeks of treatment constitute } 1 \text { cycle. } \\
\text { Cycle } 1 \text { to be } 6 \text { weeks to allow metformin } \\
\text { titration. }\end{array}$ & $\begin{array}{l}\text { metformin, } \\
\text { temsirolimus }\end{array}$ & 104 & Recruiting & NA & NCT01529593 \\
\hline $\begin{array}{l}\text { Advanced } \\
\text { cancers/ } \\
\text { metastatic } \\
\text { cancers }\end{array}$ & Phase I & $\begin{array}{l}\text { MTD of lapatinib with } \\
\text { sirolimus or metformin }\end{array}$ & $\begin{array}{l}\text { Lapatinib starting dose } 500 \mathrm{mg} \text { PO daily for } \\
21 \text { day cycle, metformin starting dose } 1000 \\
\mathrm{mg} \text { PO daily. }\end{array}$ & $\begin{array}{l}\text { metformin, } \\
\text { lapatinib }\end{array}$ & 106 & $\begin{array}{l}\text { Active } \\
\text { but not } \\
\text { recruiting }\end{array}$ & $\mathrm{NA}$ & NCT01087983 \\
\hline
\end{tabular}

Abbreviations: RR, recurrence rate; PFS, Progression free survival; PSA, Prostate specific antigen; MTD, Maximum tolerable dose; DLT, Dose limiting toxicity; pCR, Pathological complete response; RCT, Randomized control trial; CBR, Clinical benefit rate; IHC, Immunohistochemistry; CI, Confidence interval; PO, taken by mouth; QD, once a day; BID, two times a day; TID, three times a day

topoisomerase II $\alpha$ and ERK 1 / 2, along with significant elevation in pAMPK and p27 [45]. A different trial reported a decrease in tumor cell proliferation by $11.75 \%$ and a decrease in expression of ER with the use of metformin. PR expression, however, was not affected [43]. Thus far, no trial has provided any data on survival benefit with the use of metformin in endometrial cancer, though one trial is ongoing (NCT02065687).

Metformin is being assessed in combination with various anti-cancer agents for the treatment of pancreatic cancer. Presently, there are 7 ongoing and 2 completed trials (Tables 2-4). With the exception of one trial where the treatment regimen involves using metformin together with stereotactic radiosurgery (Table 4), all others are using metformin in combination with different anti-cancer agents. These include cisplatin, capecitabine, epirubicin, erlotinib, everolimus, gemcitabine, octreotide, paclitaxel, rapamycin, and FOLFOX (fluorouracil, oxaliplatin, leucovorin). The effects of metformin are being assessed mostly through clinical outcomes including progression free survival (PFS), recurrence free survival (RFS) and toxicity due to chemotherapy combination. The results from a phase II non-randomized trial showed that the combination of metformin plus paclitaxel was not well tolerated, with $42.1 \%$ patients experiencing grade $3-4$ toxicities. A total of $31.6 \%$ cases had to undergo metformin dose reduction secondary to development of diarrhea, while one case experienced febrile neutropenia which was attributed to paclitaxel. This trial reported a median overall survival (OS) of 133 days and median PFS as 43 days, but could not meet the disease control rate endpoint [46]. Another trial, consisting of 120 participants randomized to metformin or placebo arm, noted that although the combination of metformin, gemcitabine and 
Table 4: Antitumor activity of metformin in combination with radiotherapy

\begin{tabular}{|c|c|c|c|c|c|c|c|c|}
\hline Cancer type & Phase & $\begin{array}{l}\text { Primary outcome/ } \\
\text { Conclusion }\end{array}$ & Dosing regimen & Combination & $\begin{array}{l}\text { Enrollment } \\
\text { No. }\end{array}$ & Status & Results & $\begin{array}{l}\text { Clinical trial } \\
\text { identifier/ } \\
\text { Reference }\end{array}$ \\
\hline Brain & Phase I & $\begin{array}{l}\text { Number of } \\
\text { participants that } \\
\text { had adverse events } \\
\text { and the number that } \\
\text { completed the trial } \\
\text { (assessed at 8 weeks) }\end{array}$ & $\begin{array}{l}\text { Partial brain re-irradiation to a dose of } 30-35 \mathrm{~Gy} \\
\text { over } 2 \text { weeks ( } 10 \text { fractions) combined with low } \\
\text { carbohydrate diet and/or metformin }\end{array}$ & $\begin{array}{l}\text { metformin, } \\
\text { partial brain re- } \\
\text { irradiation }\end{array}$ & 18 & Not yet recruiting & NA & NCT02149459 \\
\hline $\begin{array}{l}\text { Head and } \\
\text { neck locally } \\
\text { advanced } \\
\text { squamous cell } \\
\text { carcinoma }\end{array}$ & Phase I & $\begin{array}{l}\text { MTD } \\
\text { of metformin when } \\
\text { used with cisplatin } \\
\text { plus radiation }\end{array}$ & $\begin{array}{l}\text { metformin administered in escalating doses of } \\
2000 \mathrm{mg}, 2550 \mathrm{mg} \text { and } 3000 \mathrm{mg} \text { PO starting } 1 \\
\text { week prior to the initiation of chemoradiation } \\
\text { and ending on the last day of chemo or radiation. } \\
\text { Cisplatin } 100 \mathrm{mg} / \mathrm{m} 2 \text { on days } 1,22 \text {, and } 43 \text {, } \\
\text { Radiation } 70 \mathrm{~Gy} \text { in } 2 \text { Gy once daily fractions of } \\
35 \text { fractions. }\end{array}$ & $\begin{array}{l}\text { metformin, } \\
\text { chemo-radiation } \\
\text { (with cisplatin) }\end{array}$ & 30 & Not yet recruiting & NA & NCT02325401 \\
\hline Lung & Phase II RCT & $\begin{array}{l}\text { Comparing response } \\
\text { to metformin versus } \\
\text { placebo }\end{array}$ & $\begin{array}{l}\text { Metformin for } 3 \text { weeks prior to SBRT and for } \\
1 \text { week during SBRT. Metformin dose- } 2000 \\
\mathrm{mg} / \text { day PO ( } 500 \mathrm{mg} \text { AM, } 1000 \mathrm{mg} \text { noon, } 500 \\
\mathrm{mg} \text { PM). Metformin started at } 1000 \mathrm{mg} \text { daily in } \\
\text { divided doses for } 1 \text { week. SBRT delivered per } \\
\text { standard of care. }\end{array}$ & metformin, SBRT & 70 & Recruiting & NA & NCT02285855 \\
\hline Lung & Phase II RCT & $\begin{array}{l}\text { PFS (assessed for up } \\
\text { to } 12 \text { months) }\end{array}$ & $\begin{array}{l}\text { Metformin } 500 \mathrm{mg} \text { BID PO for week } 1,1500 \\
\mathrm{mg} / \text { day in week } 2 \text { and } 2000 \mathrm{mg} / \text { day at week } 3 \\
\text { and then for a period of } 12 \text { months. Cisplatin- } \\
\text { based chemotherapy with standard radiotherapy } \\
\text { of } 60-63 \text { Gy for } 6 \text { weeks. }\end{array}$ & $\begin{array}{l}\text { metformin, } \\
\text { cisplatin-based } \\
\text { chemotherapy, } \\
\text { standard } \\
\text { radiotherapy }\end{array}$ & 94 & Recruiting & NA & NCT02115464 \\
\hline Lung & Phase IIRCT & $\begin{array}{l}\text { PFS (assessed for } \\
\text { up to } 5 \text { years) }\end{array}$ & $\begin{array}{l}\text { Metformin PO BID or TID xI4 days. Day } \\
15 \text { onwards patients receive paclitaxel IV } \\
\text { and carboplatin IV on days } 1,8,15,22,29, \\
36 \text { and undergo radiation therapy (3D-CRT } \\
\text { or IMRT) QD } 5 \text { days/week for } 6 \text { weeks and } \\
\text { receive metformin BID/TID for } 6 \text { weeks. } \\
\text { From } 28-42 \text { days after radiotherapy, patients } \\
\text { receive consolidation chemotherapy with } \\
\text { paclitaxel IV and carboplatin IV on days } 1 \text { and } \\
22 \text { and metformin PO BID/TID for } 10 \text { weeks. } \\
\text { Consolidation chemotherapy repeated every } 3 \\
\text { weeks for } 2 \text { courses }\end{array}$ & $\begin{array}{l}\text { metformin, } \\
\text { paclitaxel } \\
\text { carboplatin, } \\
\text { radiotherapy } \\
\text { (3D-CRT } \\
\text { or IMRT), } \\
\text { consolidation } \\
\text { chemotherapy } \\
\text { with paclitaxel } \\
\text { and carboplatin }\end{array}$ & 168 & Recruiting & $\mathrm{NA}$ & NCT02186847 \\
\hline Pancreas & NA & $\begin{array}{l}\text { DLT (assessed up } \\
\text { to } 21 \text { days after } \\
\text { therapy) }\end{array}$ & $\begin{array}{l}\text { Metformin PO or BID on days (-)11 to (-)1. } \\
\text { Patients then undergo stereotactic radiosurgery } \\
5 \text { days/week and receive concurrent metformin } \\
\text { PO BID for } 5 \text { weeks. Patients undergo } \\
\text { laparotomy in week } 6 \text { (or weeks 5-7). } \\
\text { Systemic therapy continues as soon as it is } \\
\text { considered feasible by treating physicians. }\end{array}$ & $\begin{array}{l}\text { metformin, } \\
\text { stereotactic } \\
\text { radiosurgery }\end{array}$ & 20 & Not yet recruiting & $\mathrm{NA}$ & NCT02153450 \\
\hline
\end{tabular}

Abbreviations: PFS, Progression free survival; DLT, dose limiting toxicity; MTD, Maximum tolerable dose; RCT, Randomized control trial; SBRT, Stereotactic body radiation therapy; 3D-CRT, 3D Conformal radiotherapy; IMRT, Intensity modulated radiation therapy; PO, taken by mouth; $\mathrm{QD}$, once a day; BID, two times a day; TID, three times a day

erlotinib was well tolerated, the 6 month survival rate was $55 \%$ in metformin arm and $66 \%$ in placebo arm. Also, no significant difference was observed in PFS and median OS between metformin users and non-users [47].

Five clinical trials (Tables 1-3) are presently working to evaluate if metformin may be of value in the treatment of prostate cancer. These include two trials that are using metformin as monotherapy and three in combination with different agents: abiraterone (NCT01677897), docetaxel (NCT01796028), and enzalutamide (NCT02339168). Data made available from one trial, a single arm window of opportunity study, showed a significant reduction in Ki67 index and 4E-BP-1 staining with no changes in pAMPK. Three of 24 patients developed grade 3-4 toxicities, indicating that the treatment was overall well tolerated [48]. The effect of metformin therapy on PFS for prostate cancer is being assessed in two trials (NCT01433913, NCT02339168), with one other trial evaluating PSA response (NCT01796028). However, presently there is no data available on survival benefit.

There is one phase II trial of metformin use in non-small cell lung cancer (NSCLC) combined with stereotactic body radiotherapy that is currently recruiting patients (NCT02285855).

There are two completed trials (Table 2, 3) on multi-histology solid tumors assessing the dose limiting toxicity (DLT) of various treatment regimens that include metformin. One of the trials used metformin in combination with 26 chemotherapy regimens for 17 tumor types on a total of 100 participants. The study was divided in two stages. In stage one, participants were randomized to receive metformin or placebo with chemotherapy. In stage two, participants of delayed arm would be crossed over to receive metformin with chemotherapy. Results showed that $46 \%$ of participants documented stable disease. In the sub-set of patients having quantifiable tumor markers, 28\% exhibited favorable changes. The participants receiving metformin together with chemotherapy showed a lower rate of DLT $(6.1 \%$ in stage one of concurrent arm, including grade 3 anemia, decrease in albumin and elevation in ALT) compared to those who received just the chemotherapy $(7.8 \%$ in stage one of delayed arm [including grade 3 syncope, dehydration and elevation of bilirubin] and $3.8 \%$ in stage two [including 
dehydration, vomiting and proteinuria]). The participants reporting DLTs in stage two of delayed arm were known cases of adverse events with chemotherapy [49]. The other trial used metformin and temsirolimus combination in 11 patients. It reported that $100 \%$ of participants had grade 1 toxicity and $82 \%$ experienced grade 2 toxicity, with DLT being reported in all 3 patients of the first cohort (grade 4 pneumonitis, grade 3 fatigue and grade 3 thrombocytopenia). In the second cohort, the dose of temsirolimus and metformin was reduced and DLT was observed in only two of eight cases (grade 4 dyspnea and grade 3 thrombocytopenia). After 2 months of treatment, 5 patients had stable disease, 1 case had partial response and 2 showed progression [50].

\section{DISCUSSION}

There is great excitement surrounding metformin as a potential anti-cancer agent. Epidemiological data has associated the use of metformin with a decrease in the risk of developing cancer and a reduced cancer related mortality. The information that has been gathered from preclinical studies has provided encouraging evidence for anticancer mechanisms of metformin. It has been suggested that metformin may well be used as a radiation sensitizer or an immunotherapy drug, in addition to a direct anti-proliferative agent for the treatment of cancer.

The anticancer mechanism of metformin has been extensively studied and attributed to mTOR inhibition. More recent data has revealed an immunomodulatory effect on cancer cells. Pre-clinical data has demonstrated that metformin can inhibit apoptosis of CD8+ TILs. In addition, it also increases the effector memory $\mathrm{T}$ cell population through phenotype switching of CD8+ TILs, thus enhancing the immune response against tumor cells [26]. The use of metformin with an experimental cancer vaccine (LmOVA) showed an increase in the number of CD8+ memory $\mathrm{T}$ cells that conferred immunity to cancer [27]. The recent breakthrough developments in immunotherapy for patients with advanced melanoma, triple negative breast cancer, and non-small cell lung cancer with check point blockade monoclonal antibodies (anti-PD-1/L1) have generated excitement in the oncology community [51-53]. Immunomodulatory properties of metformin have yet to be studied in combination with other forms of immunotherapy, in particular with check point blockade monoclonal antibodies. Further investigation into a possible synergistic effect is warranted.

The preliminary results from clinical trials assessing metformin as an anti-cancer agent have shown that metformin can significantly impact markers of tumor proliferation. A total of 19 ongoing and completed trials (Table 1) are using various surrogate markers to assess pro-apoptotic effects of metformin on cancer cells. Although majority of these trials are being performed on breast and endometrial cancer cases, a limited number of trials are also evaluating tumors of head \& neck, prostate, bladder, lung, kidney and lymphoma.

Pre-surgical window of opportunity trials in endometrial and breast cancer showed that tumor markers such as Ki67 and TUNEL (indicative of changes in cell proliferation and apoptosis respectively) exhibited favorable anti-tumor effect. Two trials demonstrated favorable changes in Ki67 and TUNEL in a subset of women without insulin resistance as compared to those with insulin resistance. Although the findings were not statistically significant, the direction of change suggests an intriguing hypothesis. The use of metformin in patients without insulin resistance may offer more benefit as compared to those with insulin resistance.

Diabetes is known to be associated with insulin resistance [54] and an impaired immune response against various pathogens $[55,56]$. The immune system responds to the proliferating tumor cells by increasing production of tumor specific lymphocytes which check tumor growth by various mechanisms [57]. Evidence from preclinical trials has described that metformin, at least in part, exerts an anti-cancer effect by inhibiting immune exhaustion of CD 8+ TILs [26], thus amplifying the existing immune action against cancer cells. Therefore, it may be hypothesized that the patients with insulin resistance have a compromised immune system, which consequently results in a sub-optimal anti-cancer effect of metformin. It might be rational to stratify outcomes according to the insulin resistance status of participants in future clinical trials in order to better appreciate the anti-cancer activity of metformin.

Fourteen ongoing trials (Tables 1-4) are presently amassing evidence to ascertain if a survival benefit is associated with the use of metformin in various malignancies. These include tumors of the breast, pancreas, lung, endometrial, brain, prostate and gynecological cancers. Thus far, there are results available from two clinical trials on metastatic pancreatic cancer, neither of which had favorable outcomes. From this data, it can be speculated that metformin may not be viable option for the treatment of advanced pancreatic cancer. The upcoming clinical trials may need to shift focus towards treating earlier stages of pancreatic cancer or using a different combination of agents with metformin to have better outcomes in advanced disease. Additional data on survival indices from multiple ongoing trials will be pivotal to draw a better conclusion.

One concern with the clinical utility of metformin is its side effect profile, particularly in combination with cytotoxic chemotherapy. Metformin is well known for causing GI upset, sometimes limiting patient compliance due to discomfort. Clinical trials have revealed a low incidence of DLTs with metformin in combination with a wide variety of chemotherapy regimens [48]. With this data, clinicians can be reassured that metformin will most likely be a tolerable addition to a chemotherapy regimen, 
and should not limit its practical utility.

\section{CONCLUSIONS}

A strong base of epidemiological and pre-clinical data has prompted attempts to probe the anti-cancer effects of metformin through clinical trials. Metformin has been shown to have a favorable effect on markers of tumor proliferation but it remains to be seen if that translates to benefit in survival rates. It is prudent to find better histology and the appropriate stage of tumors for utilizing metformin therapy. The potential use of metformin as an immunotherapy agent needs to be substantiated with further evidence to ascertain possible benefits in future.

\section{CONFLICTS OF INTEREST}

There is no conflict of interest.

\section{REFERENCES}

1. Inzucchi SE, Bergenstal RM, Buse JB, Diamant $M$, Ferrannini E, Nauck M, Peters AL, Tsapas A, Wender R and Matthews DR. Management of hyperglycemia in type 2 diabetes, 2015: a patient-centered approach: update to a position statement of the American Diabetes Association and the European Association for the Study of Diabetes. Diabetes Care. 2015; 38:140-149.

2. Grzybowska M, Bober J and Olszewska M. [Metformin mechanisms of action and use for the treatment of type 2 diabetes mellitus]. Postepy Hig Med Dosw. 2011; 65:277285.

3. Matthaei $\mathrm{S}$ and Greten H. Evidence that metformin ameliorates cellular insulin-resistance by potentiating insulin-induced translocation of glucose transporters to the plasma membrane. Diabete Metab. 1991; 17:150-158.

4. Diabetes Prevention Program Research G. Long-term safety, tolerability, and weight loss associated with metformin in the Diabetes Prevention Program Outcomes Study. Diabetes Care. 2012; 35:731-737.

5. Dowling RJ, Zakikhani M, Fantus IG, Pollak M and Sonenberg N. Metformin inhibits mammalian target of rapamycin-dependent translation initiation in breast cancer cells. Cancer Res. 2007; 67:10804-10812.

6. Mohammed A, Janakiram NB, Brewer M, Ritchie RL, Marya A, Lightfoot S, Steele VE and Rao CV. Antidiabetic Drug Metformin Prevents Progression of Pancreatic Cancer by Targeting in Part Cancer Stem Cells and mTOR Signaling. Transl Oncol. 2013; 6:649-659.

7. Yoshida S, Hong S, Suzuki T, Nada S, Mannan AM, Wang J, Okada M, Guan KL and Inoki K. Redox regulates mammalian target of rapamycin complex 1 (mTORC1) activity by modulating the TSC1/TSC2-Rheb GTPase pathway. J Biol Chem. 2011; 286:32651-32660.
8. Inoki $\mathrm{K}$, Zhu T and Guan KL. TSC2 mediates cellular energy response to control cell growth and survival. Cell. 2003; 115:577-590.

9. Gwinn DM, Shackelford DB, Egan DF, Mihaylova MM, Mery A, Vasquez DS, Turk BE and Shaw RJ. AMPK phosphorylation of raptor mediates a metabolic checkpoint. Mol Cell. 2008; 30:214-226.

10. Zakikhani M, Blouin MJ, Piura E and Pollak MN. Metformin and rapamycin have distinct effects on the AKT pathway and proliferation in breast cancer cells. Breast Cancer Res Treat. 2010; 123:271-279.

11. Vazquez-Martin A, Oliveras-Ferraros C and Menendez JA. The antidiabetic drug metformin suppresses HER2 (erbB2) oncoprotein overexpression via inhibition of the mTOR effector p70S6K1 in human breast carcinoma cells. Cell Cycle. 2009; 8:88-96.

12. Green AS, Chapuis N, Maciel TT, Willems L, Lambert M, Arnoult C, Boyer O, Bardet V, Park S, Foretz M, Viollet B, Ifrah N, Dreyfus F, et al. The LKB1/AMPK signaling pathway has tumor suppressor activity in acute myeloid leukemia through the repression of mTOR-dependent oncogenic mRNA translation. Blood. 2010; 116:4262-4273.

13. Memmott RM, Mercado JR, Maier CR, Kawabata S, Fox SD and Dennis PA. Metformin prevents tobacco carcinogen--induced lung tumorigenesis. Cancer Prev Res (Phila). 2010; 3:1066-1076.

14. Ben Sahra I, Regazzetti C, Robert G, Laurent K, Le Marchand-Brustel Y, Auberger P, Tanti JF, GiorgettiPeraldi S and Bost F. Metformin, independent of AMPK, induces mTOR inhibition and cell-cycle arrest through REDD1. Cancer Res. 2011; 71:4366-4372.

15. Kalender A, Selvaraj A, Kim SY, Gulati P, Brule S, Viollet B, Kemp BE, Bardeesy N, Dennis P, Schlager JJ, Marette A, Kozma SC and Thomas G. Metformin, independent of AMPK, inhibits mTORC1 in a rag GTPase-dependent manner. Cell Metab. 2010; 11:390-401.

16. Alfarouk KO, Verduzco D, Rauch C, Muddathir AK, Adil H, Elhassan GO and Ibrahim ME. Glycolysis, tumor metabolism, cancer growth and dissemination. A new $\mathrm{pH}-$ based etiopathogenic perspective and therapeutic approach to an old cancer question. Oncoscience. 2014; 1:777-802. doi: 10.18632/oncoscience.109.

17. Del Barco S, Vazquez-Martin A, Cufí S, OliverasFerraros C, Bosch-Barrera J, Joven J, Martin-Castillo B and Menendez JA. Metformin: multi-faceted protection against cancer. Oncotarget. 2011; 2:896-917. doi: 10.18632/ oncotarget.387.

18. Zhou X, Chen J, Yi G, Deng M, Liu H, Liang M, Shi B, Fu X, Chen Y and Chen L. Metformin suppresses hypoxiainduced stabilization of HIF-1 $\alpha$ through reprogramming of oxygen metabolism in hepatocellular carcinoma. Oncotarget. 2016; 7:873-84. doi: 10.18632/oncotarget.6418.

19. Buzzai M, Jones RG, Amaravadi RK, Lum JJ, DeBerardinis RJ, Zhao F, Viollet B and Thompson CB. Systemic 
treatment with the antidiabetic drug metformin selectively impairs p53-deficient tumor cell growth. Cancer Res. 2007; 67:6745-6752.

20. Shank JJ, Yang K, Ghannam J, Cabrera L, Johnston CJ, Reynolds RK and Buckanovich RJ. Metformin targets ovarian cancer stem cells in vitro and in vivo. Gynecol Oncol. 2012; 127:390-397.

21. Sato A, Sunayama J, Okada M, Watanabe E, Seino S, Shibuya K, Suzuki K, Narita Y, Shibui S, Kayama T and Kitanaka C. Glioma-initiating cell elimination by metformin activation of FOXO3 via AMPK. Stem Cells Transl Med. 2012; 1:811-824.

22. Song CW, Lee H, Dings RP, Williams B, Powers J, Santos TD, Choi BH and Park HJ. Metformin kills and radiosensitizes cancer cells and preferentially kills cancer stem cells. Sci Rep. 2012; 2:362.

23. Cantrell LA, Zhou C, Mendivil A, Malloy KM, Gehrig PA and Bae-Jump VL. Metformin is a potent inhibitor of endometrial cancer cell proliferation--implications for a novel treatment strategy. Gynecol Oncol. 2010; 116:92-98.

24. Storozhuk Y, Hopmans SN, Sanli T, Barron C, Tsiani E, Cutz JC, Pond G, Wright J, Singh G and Tsakiridis T. Metformin inhibits growth and enhances radiation response of non-small cell lung cancer (NSCLC) through ATM and AMPK. Br J Cancer. 2013; 108:2021-2032.

25. Martin MJ, Hayward R, Viros A and Marais R. Metformin accelerates the growth of BRAF V600E-driven melanoma by upregulating VEGF-A. Cancer Discov. 2012; 2:344-355.

26. Eikawa S, Nishida M, Mizukami S, Yamazaki C, Nakayama $\mathrm{E}$ and Udono H. Immune-mediated antitumor effect by type 2 diabetes drug, metformin. Proc Natl Acad Sci U S A. 2015; 112:1809-1814.

27. Pearce EL, Walsh MC, Cejas PJ, Harms GM, Shen H, Wang LS, Jones RG and Choi Y. Enhancing CD8 T-cell memory by modulating fatty acid metabolism. Nature. 2009; 460(7251):103-107.

28. Libby G, Donnelly LA, Donnan PT, Alessi DR, Morris AD and Evans JM. New users of metformin are at low risk of incident cancer: a cohort study among people with type 2 diabetes. Diabetes Care. 2009; 32:1620-1625.

29. Zhang P, Li H, Tan X, Chen L and Wang S. Association of metformin use with cancer incidence and mortality: a metaanalysis. Cancer Epidemiol. 2013; 37:207-218.

30. Wang L, Song Y, Wu GN and Yuan DM. Association of the metformin with the risk of lung cancer: a meta-analysis. Transl Lung Cancer Res. 2013; 2:259-263.

31. Deng D, Yang Y, Tang X, Skrip L, Qiu J, Wang Y and Zhang F. Association between metformin therapy and incidence, recurrence and mortality of prostate cancer: evidence from a meta-analysis. Diabetes Metab Res Rev. 2015; 31:595-602. doi: 10.1002/dmrr.2645.

32. Franciosi M, Lucisano G, Lapice E, Strippoli GF, Pellegrini $\mathrm{F}$ and Nicolucci A. Metformin therapy and risk of cancer in patients with type 2 diabetes: systematic review. PLoS One. 2013; 8:e71583.

33. Wu L, Zhu J, Prokop LJ and Hassan Murad M. Pharmacologic Therapy of Diabetes and Overall Cancer Risk and Mortality: A Meta-Analysis of 265 Studies. Sci Rep. 2015; 5:10147.

34. Bo S, Ciccone G, Rosato R, Villois P, Appendino G, Ghigo $\mathrm{E}$ and Grassi G. Cancer mortality reduction and metformin: a retrospective cohort study in type 2 diabetic patients. Diabetes Obes Metab. 2012; 14:23-29.

35. Currie CJ, Poole CD, Jenkins-Jones S, Gale EA, Johnson JA and Morgan CL. Mortality after incident cancer in people with and without type 2 diabetes: impact of metformin on survival. Diabetes Care. 2012; 35:299-304.

36. Zhang ZJ and Li S. The prognostic value of metformin for cancer patients with concurrent diabetes: a systematic review and meta-analysis. Diabetes Obes Metab. 2014; 16:707-710.

37. Niraula S, Dowling RJ, Ennis M, Chang MC, Done SJ, Hood N, Escallon J, Leong WL, McCready DR, Reedijk M, Stambolic V and Goodwin PJ. Metformin in early breast cancer: a prospective window of opportunity neoadjuvant study. Breast Cancer Res Treat. 2012; 135:821-830.

38. Wallace TM and Matthews DR. The assessment of insulin resistance in man. Diabet Med. 2002; 19:527-534.

39. Hadad SM, Coates P, Jordan LB, Dowling RJ, Chang MC, Done SJ, Purdie CA, Goodwin PJ, Stambolic V, MoulderThompson S and Thompson AM. Evidence for biological effects of metformin in operable breast cancer: biomarker analysis in a pre-operative window of opportunity randomized trial. Breast Cancer Res Treat. 2015; 150:149155.

40. Bonanni B, Puntoni M, Cazzaniga M, Pruneri G, Serrano D, Guerrieri-Gonzaga A, Gennari A, Trabacca MS, Galimberti V, Veronesi P, Johansson H, Aristarco V, Bassi F, et al. Dual effect of metformin on breast cancer proliferation in a randomized presurgical trial. J Clin Oncol. 2012; 30:25932600 .

41. Kalinsky K, Crew KD, Refice S, Xiao T, Wang A, Feldman SM, Taback B, Ahmad A, Cremers S, Hibshoosh H, Maurer $M$ and Hershman DL. Presurgical trial of metformin in overweight and obese patients with newly diagnosed breast cancer. Cancer Invest. 2014; 32:150-157.

42. Cazzaniga M, DeCensi A, Pruneri G, Puntoni M, Bottiglieri L, Varricchio C, Guerrieri-Gonzaga A, Gentilini OD, Pagani G, Dell'Orto P, Lazzeroni M, Serrano D, Viale G and Bonanni $\mathrm{B}$. The effect of metformin on apoptosis in a breast cancer presurgical trial. Br J Cancer. 2013; 109:27922797.

43. Schuler KM, Rambally BS, DiFurio MJ, Sampey BP, Gehrig PA, Makowski L and Bae-Jump VL. Antiproliferative and metabolic effects of metformin in a preoperative window clinical trial for endometrial cancer. Cancer Med. 2015; 4:161-173. 
44. Laskov I, Drudi L, Beauchamp MC, Yasmeen A, Ferenczy A, Pollak M and Gotlieb WH. Anti-diabetic doses of metformin decrease proliferation markers in tumors of patients with endometrial cancer. Gynecol Oncol. 2014; 134:607-614.

45. Mitsuhashi A, Kiyokawa T, Sato Y and Shozu M. Effects of metformin on endometrial cancer cell growth in vivo: a preoperative prospective trial. Cancer. 2014; 120:29862995.

46. De Celis Ferrari ACR, Pfiffer TEF, Alex AK, Nebuloni DR, Carneiro AQ, Capareli FC, Leite LAS, Braghiroli MIFM, Lobo J, Hoff PM and Riechelmann RP. Phase II trial of metformin and paclitaxel for patients with gemcitabinerefractory advanced adenocarcinoma of the pancreas. ASCO Meeting Abstracts. 2014; 32:e15196.

47. Wilmink J, Kordes S, Zwinderman K, Mathot R, Punt CJA and Richel D. A phase II randomized, placebo controlled study to evaluate the efficacy of the combination of gemcitabine, erlotinib, and metformin in patients with locally advanced or metastatic pancreatic cancer. ASCO Meeting Abstracts. 2014; 32:4021.

48. Joshua AM, Zannella VE, Downes MR, Bowes B, Hersey K, Koritzinsky M, Schwab M, Hofmann U, Evans A, van der Kwast T, Trachtenberg J, Finelli A, Fleshner N, Sweet J and Pollak M. A pilot 'window of opportunity' neoadjuvant study of metformin in localised prostate cancer. Prostate Cancer Prostatic Dis. 2014; 17:252-258.

49. Kritharis A, Caplain J, Rajagopal S, Grimm E, Tsichlis PN, Martell R and Saif WM. A phase I study of metformin and chemotherapy in solid tumors. ASCO Meeting Abstracts. $2014 ; 32: 2560$.
50. MacKenzie MJ, Ernst S, Johnson $\mathrm{C}$ and Winquist E. A phase I study of temsirolimus and metformin in advanced solid tumours. Invest New Drugs. 2012; 30:647-652.

51. Barbee MS, Ogunniyi A, Horvat TZ and Dang TO. Current Status and Future Directions of the Immune Checkpoint Inhibitors Ipilimumab, Pembrolizumab, and Nivolumab in Oncology. The Annals of pharmacotherapy. 2015.

52. Pembrolizumab shows potential in breast cancer. Cancer Discov. 2015; 5:100-101.

53. Larkin J, Chiarion-Sileni V, Gonzalez R, Grob JJ, Cowey CL, Lao CD, Schadendorf D, Dummer R, Smylie M, Rutkowski P, Ferrucci PF, Hill A, Wagstaff J, et al. Combined Nivolumab and Ipilimumab or Monotherapy in Untreated Melanoma. The New England journal of medicine. 2015; 373:23-34.

54. Groop L. Pathogenesis of type 2 diabetes: the relative contribution of insulin resistance and impaired insulin secretion. Int J Clin Pract Suppl. 2000; :3-13.

55. Moutschen MP, Scheen AJ and Lefebvre PJ. Impaired immune responses in diabetes mellitus: analysis of the factors and mechanisms involved. Relevance to the increased susceptibility of diabetic patients to specific infections. Diabete Metab. 1992; 18:187-201.

56. Moutschen M. [Alterations in natural immunity and risk of infection in patients with diabetes mellitus]. Rev Med Liege. 2005; 60(5-6):541-544.

57. Hadrup S, Donia M and Thor Straten P. Effector CD4 and CD8 T cells and their role in the tumor microenvironment. Cancer Microenviron. 2013; 6:123-133. 